\title{
Revize národních mýtů Dušanem D. Pařízkem
}

\section{Dušan D. Pařizek's Revision of National Myths}

Iva Mikulová

\begin{abstract}
Abstrakt
Cílem přispěvku je analyzovat inscenační postupy režiséra Dušana D. Pařízka na příkladu tři vybraných inscenací: Wilhelm Tell, Schauspielhaus Zürich, Pfauen, 2013; König Ottokars Glück und Ende, Volkstheater Wien, 2019, a Die Hermannsschlacht, Schauspiel Leipzig, 2019. $\checkmark$ těchto inscenacích se Pařizek snaží rekonceptualizovat stávající interpretační a jevištní tradici těchto národních mýtů v zemích jejich vzniku. Autorka studie nahliží Pařízkovy interpretační postupy, zaměřuje se na dramaturgické úpravy textů, scénické pojetí a herectví. Reflektuje také kritické zhodnocení režisérovy tvorby. Jedním z cílů studie je nahlédnout Pařízkovu tvorbu jako apelativní a kriticky vymezující se vưči aktuálnímu politickému dění ve střední Evropě.
\end{abstract}

\section{Klíčová slova}

Dušan D. Pařizek, Wilhelm Tell, König Ottokars Glück und Ende, Die Hermannsschlacht, národní mýtus

\begin{abstract}
The aim of this contribution is to analyse Dušan D. Pařizek's directing method using the following three selected productions: Wilhelm Tell, Schauspielhaus Zürich, Pfauen, 2013; König Ottokars Glück und Ende, Volkstheater Wien, 2019, and Die Hermannsschlacht, Schauspiel Leipzig, 2019. In these productions, Pařizek tries to reconceptualise the existing interpretative and stage tradition of the national myths in the countries of their origin (Switzerland, Austria, and Germany). The author of the article examines Pařizek's interpretative approach, focuses on the dramaturgical adaptation of the texts, scenic concepts, and acting. She furthermore reflects the critical response to the director's work. One of the aims of the article is to view Pařízek's work as appellative and critical towards the current political happenings in Central Europe.
\end{abstract}

\section{Key words}

Dušan D. Pařizek, Wilhelm Tell, König Ottokars Glück und Ende, Die Hermannsschlacht, national myth 
V roce 2019 vzbudila u rakouské i české divadelní kritiky výrazný ohlas inscenace Dušana D. Pařízka König Ottokars Glück und Ende ${ }^{1}$ [Sláva a pád krále Otakara] z vídeňského Volkstheateru (prem. 8. 1. 2019). Zájem české odborné veřejnosti je pochopitelný vzhledem k tomu, že české publikum se s tvorbou režiséra dnes již legendární éry Divadla Komedie (2002-2012) může seznámit pouze ojediněle. Od svého odchodu z Komedie totiž Pařízek režíruje téměř výlučně v německojazyčném divadelním prostoru (např. Schauspielhaus Hamburg, Deutsches Theater v Berlíně, Volkstheater ve Vídni a další). Svůj podíl na české recepci inscenace měla nejen dostupnost Vídně z Brna nebo z Prahy, ale také česká repríza ve Stavovském divadle v rámci Pražského divadelního festivalu německého jazyka (uvedeno 24. 11. 2019). Jak píše divadelní kritik Vladimír Mikulka:

Po lehce kontroverzním přijetí ve Vídni se Král Otakar přijel představit do Prahy, kde byl očekáván se zvědavostí, a snad i s trochu potouchlým zájmem, jak to Pařízek zastydle habsburkomilným Rakušákům nandal (aniž by ovšem režiséra kdokoli podezíral z nějakého čechomilného vlasteneckého nadšení). (MIKULKA 2020: 68)

Mikulkova, jistě lehce nadsazená perspektiva, ve mně vzbudila otázky, z jaké pozice Pařízek něco někomu „nandává“. Uvažujeme-li o režisérovi, jehož umělecká koncepce realizovaná ve zmíněném Divadle Komedie zahrnovala kulturní region střední Evropy a v níž hledal podle vlastního vyjádření „kolektivní duši“ (např. POLÍVKOVÁ 2008: 6-7; PROKOP 2010) nesvázanou geografickými hranicemi států střední Evropy. Lze rozmýšlet o takto národnostně vymezeném hledisku u režiséra, který prvních dvacet let svého života strávil v německojazyčných zemích, do kterých se k divadelní práci opakovaně vrací až doposud?

Za zájmem, který Otakar vyvolal u české divadelní kritiky (např. MACHALICKÁ 2019; RESLOVÁ 2019), zůstala skryta skutečnost, že Pařízkovo „nandání“ Rakušanům je v případě Otakara jednou z několika inscenací, v nichž Pařízek zcela koncepčně boří mýty národních historických dramat, za jaké je Otakar v Grillparzerově rodném Rakousku považován. ${ }^{2}$ Že zcela programově šlape na „kuří oka“ národnostně patriotických interpretací těchto hrdinů-zakladatelů, když u Rudolfa připomíná jeho švýcarský původ, který Rakušané rádi přehlížejí. Nejinak je tomu u další z trilogie inscenací rekonceptualizující národní mýty: švýcarský národní lidový hrdina Vilém Tell ze Schillerova dramatu se v Pařízkově inscenaci (Wilhelm Tell, prem. 14. 3. 2013, Schauspielhaus Zürich, Pfauen) potácí pod vlivem halucinogeních drog a svého syna, navzdory mýtům o jeho precizních střeleckých schopnostech nakonec zastřelí. Tuto tematickou trilogii prozatím uzavírá inscenace Die Hermannsschlacht,

1 V českém překladu také Štěsti a pád krále Otakara nebo Sláva a pád krále Otakara (pod tímto názvem inscenaci uvádí v prvním českém překladu hry Městská divadla pražská, prem. 2019). Ve studii budu používat tento oficiální český překlad.

2 Pro upřesnění lze dodat, že tím rakouským hrdinou dramatu je Rudolf Habsburský, nikoli titulní postava Otakara, skrze jehož pád naopak autor poukazuje na politickou a hrdinskou zdatnost Rudolfa. Proto budu v této studii hovořit ve srovnání s Tellem a Hermannem primárně o Rudolfovi, nikoli o Otakarovi. 
česky Hermanova bitva ${ }^{3}$ (poprvé ji Pařízek uvedl v Deutsches Schauspielhaus v Hamburku, prem. 28. 9. 2007, podruhé se ke Kleistovu titulu vrátil v Schauspiel Leipzig, prem. 3. 10. 2019) o Arminiovi (zvaném Hermann der Cherusker), který sjednotil germánské kmeny a vedl vzpouru proti římské nadvládě. ${ }^{4}$ Všechna zmíněná dramata Pařízek uvedl ve vlastních, text značně redukujících úpravách. ${ }^{5}$ Dramaturgem Viléma Tella a Otakara byl Pařízkův dlouholetý spolupracovník Roland Koberg, inscenaci Die Hermannsschlacht dramaturgoval Matthias Döpke. Na základě vybraných analytických sond do těchto inscenací se pokusím zodpovědět otázky: Proč si Pařízek vybírá právě tyto hry tvořící „klasický“ dramatický kánon německé, rakouské a švýcarské divadelní literatury, které vznikly na začátku 19 . století, ${ }^{6} \mathrm{v}$ době sílících nacionalistických tendencí ve střední Evropě? Je jeho hlavním cílem skutečně někomu něco „nandávat“, bořit historické/politické mýty a potažmo inscenační tradici uvádění těchto v historii nacistickými režimy zneužitých dramat? Nebo je toto boření mýtů také prostředkem k varování před současnými společenskými jevy, jako jsou vzrůstající nacionalismus a populismus? Jaké inscenační strategie k tomu ve vybraných třech inscenacích volí a můžeme jejich výsledné podoby označit za politické divadlo? A v neposlední řadě: z jaké občanské, národnostní perspektivy tedy Pařízek tyto inscenace uvádí?

\section{„Jsi Čech nebo Němec?”}

Na tuto otázku Kamily Polívkové (2008: 7) Pařízek odpovídá: „Je v tom snad nějaký rozdíl?“, čímž zpochybňuje smysl dotazu, který by jej zařazoval pouze do jednoho vybraného národa:

Mluvím o společném ,jazyce“. A tím nemyslím němčinu nebo češtinu. Jde o společné vnímání určitých skutečností, společné vzpomínky, sdílení duchovního prostředí založeného na konkrétních hodnotách. Nelze to vymezit ani geograficky, jedná se spíš o kulturní region, jakým

3 Kleistovo drama není dosud přeloženo do češtiny, možné překlady jsou: Hermanova bitva, Heřmanova bitva, Bitva v Teutoburském lese. V textu používám původní německý název, u dvou dalších her uvádím název českého překladu.

4 V analýzách jednotlivých inscenací vycházím z vlastního diváckého zážitku, vyjma hamburské inscenace (viz záznam v bibliografii) jsem všechny zbylé viděla na jejich premiérách. Ve všech případech pracuji také se záznamy zapůjčenými z archivů daných divadel.

$5 \quad$ K této trilogii rozrušování národních mýtů bychom mohli zařadit také inscenaci Kauza Schwejk (prem. 11. 6. 2015), uvedenou v česko-německé koprodukci (Studio Hrdinů a Theater Brehmen), reprízovanou na prestižním rakouském divadelním festivalu Wiener Festwochen. Nechávám ji záměrně bez zřetele, přestože by se do zvoleného dramaturgického rámce hodila středoevropským kontextem, stejně jako mytizací postavy Švejka. Na druhou stranu se však nejedná o zakladatelský politický mýtus (mnohem více bychom měli hovořit o jeho funkci identifikační, občanské) a také převedení na jeviště bylo založeno na jiné formě úpravy, a sice dramatizaci prozaického textu.

6 V časové souslednosti: Vilém Tell (napsáno, publikováno a poprvé uvedeno 1804), Die Hermannsschlacht (napsáno 1808, publikováno 1821, poprvé uvedeno 1839) a Sláva a pád krále Otakara (napsáno 1823, publikováno a poprvé uvedeno 1825). 
je např́íklad Střední Evropa. Ten má základ v souvislostech, které přesahují hranice jednotlivých států i jazykové bariéry. (PROKOP 2010)

Tato životní a potažmo i následně umělecká přesvědčení formoval jeho status dítěte emigrantů: „Vyrůstal jsem v několika zemích - celá ta cesta začínala v Rakousku, posléze Nizozemí, Švýcarsko, zase Nizozemí, pak zase krátce Rakousko - trauma z Rakušanů, z té jejich němčiny - nakonec Německo, kde proběhla větší část mé socializace“ (POLÍVKOVÁ 2008: 7). Do této socializace můžeme zahrnout kromě Pařízkovy divácké zkušenosti německojazyčného divadla v devadesátých letech i studium komparatistiky a divadelní vědy na Univerzitě Ludvíka Maxmiliána v Mnichově.

S Pařízkovou národností je libovolně nakládáno podle účelu, k němuž má zrovna v tu chvíli sloužit. „Češi mě považují za Němce, Němci za Čecha, Moravané za Pražáka. Jsem prostě cizí“ (POLÍVKOVÁ 2008: 7). Svévolné nakládání s Pařízkovou identitou glosuje divadelní kritik Vojtěch Varyš v recenzi na švýcarského Viléma Tella:

Ostatně propagační materiály curyšského divadla lákají na Pařízkovy inscenace slogany typu: ,jak si poradil český režisér s tradičně švýcarskou látkou“, a podobně. Není důvod si cokoli zastírat: i když známe smysl marketérů pro realitu, v německy mluvících zemích je Pařízek českým režisérem, potažmo „divadelníkem z Východu“, zatímco u nás byl často vnímán jako Němec, či dokonce „cizák“. Přičemž na každé straně hranice se potlačuje a zdůrazňuje ta opačná část. (VARYŠ 2015)

Ve snaze pojmenovat, kam vlastně Pařízek z národnostního hlediska patří, je možné o Pařízkovi uvažovat jako o cizinci. Cizinec je ze sociologického hlediska definován jako „ten, kdo nikam nepatří“ (RADIMSKÁ 2001: 64). ${ }^{7}$ Podle německého sociologa a filozofa Georga Simmela je cizincova nesvázanost s minulostí jeho výhodou: „[...] cizinec je svobodnější, prakticky i teoreticky, ve svém pohledu na poměry je méně zatížen předsudky, hodnotí je podle obecnějších, objektivnějších ideálů a není ve svém jednání spoután zvykem, pietou a precedenty“ (SIMMEL 1997: 29). Cizinec nabývá svobody odstupu, která je dána jeho neustálou proměnou společnosti, v níž se nachází: „Udržuji si odstup, abych byl připraven, až se zase vydám na cestu“ uvádí Pařízek (POLÍVKOVÁ 2008: 7). Tento pohyb a odstup zároveň umožňuje kritický náhled a srovnání, pojmenování skutečností, jež nejsou viditelné zvnitřku dané společnosti. Uvažujme tedy v kontextu této studie o Pařízkovi jako o postmoderním tulákovi (viz BAUMAN 2006: 46-49), pro něhož je každá zastávka jen přechodná. Na př́íkladu zvolených inscenací se pokusím poukázat na bezprecedentní, pietou nespoutané interpretace a jevištní ztvárnění kanonických národních dramat, jež tematizují tři zakladatele: švýcarského Viléma Tella, německého Hermanna a rakouského Rudolfa Habsburského. A pojmenovat způsob, kterým Pařízek k těmto revizím interpretačních tradic přistupuje.

$7 \quad$ Z přehledové studie Radky Radimské vyplývá, že většinu teoretiků zabývajících se konceptem cizosti, spojuje bud' vlastní emigrace nebo status potomka emigrantů. Tedy osoby, které si svou cizost uvědomovali na základě prožitku vzdálení se rodné zemi. 


\section{Politický mýtus}

Tituly Pařízkových inscenací uváděných v České republice a v německojazyčných divadlech se na první pohled výrazně liší: Zatímco v Divadle Komedie v letech 2002-2012 převažovala dramatika „kálečů do vlastního hnízda“ (Elfriede Jelinek, Thomase Bernharda, Petera Handkeho a Wernera Schwaba), těm zahraničním dominuje „povinná literatura“ klasického dramatického kánonu 18. a 19. století (od Lessinga a Schillera ke Kleistovi a Gotheovi). ${ }^{8}$ Tuto na první pohled heterogenní dramaturgii však spojuje koncepce hledání kolektivní identity dnes již politicky autonomních národů, které byly dříve součástí Habsburské monarchie. K pojmenování společných konstant přistupuje Pařízek skrze precizní demontáž, vycizelování národních klišé a stereotypů dané země. Ty následně persifluje a tím poukazuje na jejich zkostnatělost, stereotypnost. V textech Bernharda nebo Schwaba se těchto kritik vůči vlastním národům dopouštějí sami autoři (a Pařízek poté ještě texty dointerpretovává); u německé klasiky se tímto novým interpretem stává sám Pařízek.

Historická nebo také národní dramata o Tellovi, Hermannovi a Rudolfovi můžeme zařídit k žánru politických mýtů, př́ípadně ještě konkrétněji z hlediska politické sociologie k žánru zakladatelských mýtů. Tyto slouží na jedné straně k tvorbě kolektivní identity, na straně druhé k legitimizování moci. Jak uvádí německý politolog zaměřující se na politické mýty 19. století Rudolf Speth, v př́ípadě těchto mýtů se jedná o narace, které se vztahují k jednání kolektivu a slouží k jeho popsání, tedy tematizují kolektivní identitu (SPETH 2000: 12). Tyto úvahy rozvíjí berlínský politolog Herfried Münkler, který se ve své knize Němci a jejich mýty [Die Deutschen und ihre Mythen, 2009] zabývá typologií německých mýtů a jejich přehodnocením. Podle něj tyto mýty slouží k utváření kolektivní paměti, která má pro identitu politického společenství zásadní význam. Vznik národních mýtů v dramatické tvorbě nevyhnutelně souvisí s politickými událostmi přel. 18. a 19. století: „Pod vlivem Francouzské revoluce a následné politické dynamiky nastala v Německu koncem 18. století poptávka po národních mýtech a národních hrdinech, které a kteří by zaujali místo odumírajících hrdinských mýtů dvorské společnosti“ (MÜNKLER 2017: 7). Hledání odpovědi na otázku „Kdo jsme my?“ a jaká je naše kolektivní identita se odvíjí od revolučních snah začátku 19. století vytvořit z obyvatel „národ“ (Assmann in SPETH 2000: 151), tedy s rozvojem nacionalistických tendencí této doby.

\section{Geneze generování hrdiny}

Mýtus těchto zakladatelů ve zpracování Schillerem, Kleistem a Grillparzerem je dodnes uchováván v kolektivní paměti jednotlivých národů, a to nejen skrze literární, ale také divadelní tradici. Tell je znám coby osvoboditel Švýcarska a bojovník za svobodu stvrzenou roku 1291 vznikem Švýcarské konfederace, Hermann jako první historicky dolo-

8 Třetí podstatnou dramaturgickou linii zpodobňují Pařízkovy dramatizace románů současných autorů Davida Grossmana, Christopha Heina a dalších. 
žitelný Němec, ${ }^{9}$ který se svými vojsky porazil v roce 9 n. 1. římské legie, a Rudolf jako panovník stojící u zrodu rakouského národa. Tell není stratég a rétor, jeho nástrojem je kuše, kterou umí mistrně ovládat a s níž sestřelí jablko z hlavy svého syna, což v důsledcích znamená uhájení svobody celého národa před habsburským fojtem Gesslerem. Hermann si naopak ruce nešpiní, krev ze zabité medvědice zanechá stopy na jeho ženě Thusneldě, kterou využije ke svým manipulacím. Rudolf v klidu vyčkává na Otakarovy chyby a v rozhodující bitvě poruší stávající pravidla boje a v touze po moci zaútočí na Otakarova vojska z týlu. Přestože všechna tři dramata vznikají v rozmezí dvaceti let, ke zvolenému námětu autoři přistupují z různých perspektiv a skrze hlavní hrdiny koncipují politický mýtus v rozličných rovinách.

Legendu o udatném hrdinovi Tellovi znal Schiller pravděpodobně od Goetha, který mu ji vyprávěl po návratu ze svých cest. Švýcarský národní mýtus je tedy postaven na zpracování zprostředkovaného vyprávění Němcem, který Švýcarsko nikdy nenavštívil. Schiller své drama píše v roce 1803 (dokončeno 1804), v dozvuku Velké francouzské revoluce a deklarace zaručující občanská práva a svobody. V té době doznívá také francouzská invaze do Švýcarska, které bylo pod označením „Helvétská republika“ integrováno do francouzské teritoriální politiky. Tuto ztrátu autonomie jednotlivých kantonů proměnil až Vídeňský kongres v roce 1815, kterého se už ale Schiller nedožil. Pro Francií okupované Švýcarsko své doby nalezl historickou paralelu ve 13. století, kdy se Švýcarsko potýkalo s mocenskou nadvládou Habsburků, které v dramatu zpodobňuje postava fojta Gesslera.

Zatímco Schillerovo drama s idealizovanou postavou Tella je situováno do kraje pastýřů u Lucernského jezera, který obestírají lidskou silou neporazitelné živly a nad nimiž bdí všudypřítomný bůh, drama Heinricha von Kleista napsané o čtyři roky později se odehrává v mlhou zahaleném a bažinami vystlaném prostoru Teutoburského lesa. Soudobým zpracováním této historicky podstatné bitvy z roku $9 \mathrm{n}$. 1. Kleist reaguje na porážku Německa francouzskými napoleonskými vojsky v roce 1807 a prohry Pruska v rámci Války čtvrté koalice. ${ }^{10}$ Oproti Schillerově dramatu však u Kleista dochází k podstatnému rozdílu: Tell ve své osvoboditelské snaze jedná značně pudově, bez rozvahy a výrazně individualisticky. Naproti tomu Hermann v Kleistově pojetí11 ${ }^{11}$ vstoupil do dějin dramatu jako archetyp válečníka-stratéga, manipulátora a rétora, který si je od počátku vědom nedostatečných kvalit vlastních vojsk (a také rozbrojů panujících mezi jednotlivými germánskými kmeny), a tedy si své vítězství jistí především zákulisními intrikami (do nichž se neštítí zahrnout i svou ženu Thusneldu). Strategii prokázal již volbou terénu v bažinatém lesním porostu, ve kterém se římské legii nebyly schopné orientovat, čímž ale porušil pravidla otevřené symetrické polní bitvy.

9 Tyto závěry však již byly odborníky také zpochybněny a redefinovány, viz (MÜNKLER 2017).

10 Lze tak vysledovat paralelu mezi římskými legiemi, proti kterým Hermann svede vítěznou bitvu, a francouzskými vojsky, pruským vojskem a armádou Cherusků, stejně jako mezi Svéby (př́íbuznými germánskými kmeny) a Rakouskem.

11 V německojazyčné literatuře existuje rozsáhlé množství publikací, které se zabývají politickými mýty. V kontextu Die Hermannsschlacht můžeme zmínit např. knihu Andrease Dörnera Politischer Mythos und Symbolische Politik (1996). 
V nastíněné typologii postav - lidový hrdina bez politických ambicí Tell a mocenský manipulátor Hermann - se zrcadlí také dvě hlavní postavy hry Sláva a pád krále Otakara z roku 1821. Franz Grillparzer, klasik rakouského divadla 19. století a „první muž bez vlastností v habsburské literatuře“ (MAGRIS 2010: 82)12, proti sobě postavil politického stratéga Rudolfa a ctižádostivého snílka Otakara: „A přitom právě Rudolf, ten teoretik trpělivosti, jedná prozíravě, protože opatrnost je politickým uměním, kdežto Otakar sní o velkých činech, ale pasivně se nechává ukolébat apolitickým snem“ (MAGRIS 2010: 85). Je-li Schiller protihabsburský, uvádějící v život legendární postavu bojovníka hájícího svobodu a zájmy starého Švýcarska proti rakouským vlivům, Kleist a Grillparzer naopak stojí na straně Prusů a Rakušanů, kteří si brání svůj národ před Napoleonovou invazí. Postavu Napoleona chtěl Grillparzer původně učinit středobodem svého dramatu, ovšem poté svi̊j nápad z obav cenzurního zákazu přehodnotil a zvolil raději českého panovníka. Na jeho př́kladu se naplnil osud ctižádostivého titánského hrdiny, který je předurčen k pádu, protože není součástí žádného vyššího harmonického řádu či zákona (MAGRIS 2002: 104).

$\mathrm{V}$ rozsahu této studie se nelze věnovat kompletní inscenační tradici těchto zakladatelských mýtů a proměnám interpretací, kterých hry od svých prvních uvedení doznaly. V kontextu uvažování o jejich politickém a společenském dosahu je ovšem příznačné, že dramata Vilém Tell i Die Hermannsschlacht byla zneužita nacistickou propagandou. Ǩíšský ministr propagandy Joseph Goebbels označil Viléma Tella za „Führerdrama“ (drama vůdce), nebot v Tellovi mocenští představitelé Třetí ř́řse spatřovali silného vůdce. V roce 1941 však došlo v důsledku několika pokusů o atentát na Adolfa Hitlera k zákazu uvádění tohoto dramatu, které mohlo být interpretováno také zcela protichůdným způsobem: jako varování před neomezenou mocí vůdce. Ještě více ovšem s ideologií nacionálního socialismu rezonovalo Kleistovo drama s prototypem vůdce v postavě Hermanna. Jenom v sezóně 1933/1934 lze dohledat 146 uvedení této hry. ${ }^{13}$ Její propagandistické zneužít pochopitelně vedlo k oslabení zájmu o její inscenování po skončení 2. světové války. ${ }^{14}$ Otakar se oproti těmto dvěma dramatům vyznačuje mnohem menší inscenační tradicí, která není spjata s obdobím nacionálního socialismu. Zmínit však můžeme uvedení u př́ležitosti znovuotevření Burgtheatru a k podpisu státní smlouvy znovuobnovené Republiky Rakousko, které ve svém dramoletu Burgtheater perziflovala Elfriede Jelinek (GRILLPARZER 2019b: 67). ${ }^{15} \mathrm{O}$ více než půl století později je Pařízko-

12 Autorem tohoto označení je italský spisovatel Claudio Magris, který ve své tvorbě zkoumá habsburský mýtus v literaturách zemích střední Evropy.

13 Kleist se uvedení své hry nedočkal, nebot’ spáchal sebevraždu tř̌i roky po jejím dopsání. Nedožil se tak ani rozhodují bitvy napoleonských válek u Lipska v roce 1815.

14 Inscenační tradicí zatížené drama rehabilitoval v tehdejším západním Německu až v roce 1982 Claus Peymann v nejslavnější inscenaci svého bochumského období. Jeho levicové vyznění se vymezovalo vůči zneužití této hry ve 2 . světové válce a zároveň znamenalo průlom v západoněmecké divadelní tradici, oproštěné v období Adenauerovy vlády od politických témat a otázek (CARLSON 2016: 17). V letech 2019 a 2020 dochází k opětovnému uvádění této hry, kromě Pařízkovy inscenace ji v rakouském Burgtheateru pietně a realisticky zhmotnil režisér Martin Kušej a v Schauspiel Köln ji nahlédl jako relativizující Lehrstück (WESTPHAL 2020) kontroverzní režisér Oliver Frljić.

$15 \mathrm{Z}$ nastudování uvedených před Pař́izkovou premiérou můžeme zmínit inscenaci Martina Kušeje z roku 2005 pro Salzburger Festspiele, po jejichž skončení byla inscenace převedena do vídeňského Burgtheateru. 
vým záměrem tato dramata Pařízek inscenovat proti jejich možnému nacionalistickému výkladu. Redefinuje jejich konvencionalizované interpretace, rozbíjí je s př́iznačností, s níž nechává ve svých inscenacích rožrezávat části kulis na třísky, a v nastalé spoušti vyvstává varování před nacionalistickým a xenofobním smýšlením.

\section{Dogmatický minimalismus}

Pařízkův režijní rukopis vykazuje už dvě desetiletí konzistentní estetické rysy označované jako „dogmatický minimalismus“ (PAŘÍZEK a MAŠÍN 2010). Jsou inspirovány filmovým manifestem Dogma 95, z něhož Pařízek přejímá hlavní myšlenku jednoduchosti, koncentrovanosti a minimalismu a podřizuje je zákonitostem divadelního umění. Konkrétně to pro něj znamená:

[...] omezení hereckých, scénografických, hudebních a inscenačních prostředků na to nejnutnější, realizace scénografických řešení, která jsou vyplývající z výrazné interpretace textů, prostorové koncepce, které se vždy zakládaly na využití autentických materiálů - to všechno vedlo, v rámci našich omezených možností1 ${ }^{16}, \mathrm{k}$ maximální koncentraci na zvolená témata [...] (POLÍVKOVÁ 2009)

Tato koncepce se u Pařízka synergicky realizuje v několika rovinách, jelikož on sám bývá téměř bez výjimky autorem úpravy, scénografie, hudby a režie. Po jeho zásahu do textu zůstávají z původního dramatu nebo prozaického textu (jedná-li se o dramatizaci románu) skutečně jen skelety osekané o postavy a repliky. Tento skelet převádí režisér na jeviště v minimalistické scénografii vycházející z jednoduchých geometrických tvarů a sestavených bez výjimky z dřeva (dřevěné latě sestavené do tvaru kostky, nakloněná šikma vytvořená z dřevěných krychlí apod.). ${ }^{17}$ Vizuálně koherentní koncepci scénografie v jednotlivých inscenacích doplňují lokální atributy spjaté s daným tématem, které se promítají také do kostýmů (u všech tř́i popisovaných inscenací je autorkou kostýmní výtvarnice Kamila Polívková, dlouholetá spolupracovnice Dušana D. Pařízka). V prázdném scénickém prostoru tyto atributy, odkazující k národním klišé a stereotypům (např. kravské zvony a švýcarské dřeváky ve Vilému Tellovi), o to silněji rezonují a lokalizují děj. V hudební rovině je příznačný minimalistický, až ambietní motiv, který se v inscenaci průběžně opakuje. ${ }^{18}$

16 Tato vsuvka se vztahuje k finančním podmínkám provozu Divadla Komedie.

17 Jedním ze signifikantních vizuálních znaků Pařízkových inscenací je projekce skrze zpětný projektor. Podobně signifikantní ovšem je, že v žádné ze tří analyzovaných inscenací není použit. Domnívám se, že tato skutečnost je podmíněna charakterem literární předlohy: zpětné projektory se v posledních letech objevují především v inscenacích dramatizací prozaických předloh, v nichž Pařízek uplatňuje rozdîlné interpretační postupy.

18 V hudební rovině stř́ídá Pařízek dva základní principy: hudbu na jevišti bud' produkuje některý z herců na mnohdy k tomu speciálně vyrobený nástroj (např. v Otakarovi, autorem hudby v Otakarovi je herec Peter Fasching, představitel Záviše z Falkenštejna, se kterým Pařízek v posledních dvou letech opakovaně spolupracuje jako s autorem hudby), nebo v inscenaci zazní známé popové songy (což bylo př́značné např. pro tvorbu v Divadle Komedie). Ve sledovaných inscenacích dochází k jediné výjimce, hudbu k Vilému Tellovi složil Roman Zach. 
K úspornosti směřuje také režijní vedení herců ke koncentrovanému projevu, případně projevu založenému na výrazných charakteristických rysech dané postavy. ${ }^{19}$ Pařízek už více než desetiletí rozvíjí svůj postulát: „Autentické a spontánní herectví je jedním z předpokladů pro zkoumání možných jazyků současného divadla“ (PROKOP 2010). S každou jeho další režií je patrná modifikace hereckého ztvárnění (vycházející samozřejmě také z proměnlivých podmínek během různých divadelních hostování), je možné všímat si valér, posunů principu minimalistického divadla. Věcné, od velkých gest oproštěné herectví umožňuje oslovit diváka, nepůsobit primárně na jeho prožívání, ale vstoupit s ním do komunikace. Apelovat ${ }^{20}$ na něj přiznanou divadelností, rozrušováním iluzivních principů: herci se do děje zapojují z hlediště, oslovují diváky, podávají si s nimi ruce, nabízejí jim občerstvení (především alkoholické), nasazují si paruky, umělé vousy, obsluhují technické zařízení, je-li přítomno na jevišti a další. Z těchto důvodů se v Pařízkových inscenacích často svítí plným světlem, které výrazně exponuje jemné herecké nuance; herec předává myšlenku/téma, jeho úlohou není připravit divákovi „podívanou“. ${ }^{21}$ Více než hodnocení estetických kategorií je tak nutné se u Pařízkových inscenací zamýšlet nad nastavením komunikačního pole mezi herci a diváky.

\section{„Jablko je zasaženo!"}

V rámci jednotlivých inscenací se zaměřím na výrazové prostředky, vycházející z výše pojmenovaného minimalismu, skrze které se Pařízek snaží dekonstruovat národní mýty a relativizuje jejich historický význam. Ve všech zvolených inscenacích vychází režisérova koncepce z podobné interpretační roviny, postavené na perzifláži, grotesce a ironii, ovšem jejich vyznění se v každé inscenaci liší a dává důraz na jinou interpretaci. Dramatický text Pařízkovi slouží jako předloha, $\mathrm{k}$ níž staví diskurzivní komentář plný zpochybnění, relativizování nebo dokonce subverzivně popírající tradiční výklad textu. Posouvá konflikty dramatu na základě jeho pečlivého čtení, krácení, úprav, v rámci kterých vytahuje na povrch významy, které jsou v dramatu implicitně obsaženy.

$\mathrm{Z}$ toho důvodu Schillerových téměř pět desítek postav redukuje na jedenáct, hlavní partnerské dvojice a zástupce jednotlivých kantonů, kteří pars pro toto reprezentují celé kantony. K výrazným posunům dochází v interpretaci hlavních postav Tella a Gesslera, jakožto mužů, mezi nimiž se odehrává hlavní konflikt už v Schillerově dramatu: Tell zpupně odmítá poklonit se Gesslerově klobouku, který značí poslušnost

19 V českém kontextu můžeme připomenout jako příklad zmíněné herecké techniky precizní výstavbu postav v inscenaci Nadváha, nedůležité: neforemnost (Divadlo Komedie, 2008), v níž např. Vanda Hybnerová nekarikuje postavu hospodské skrze ustálené verbální a nonverbální stereotypy spojené s postavou hospodské, ale na základě těchto příznačností buduje postavu jakoby zcela novou.

20 Tento pojem volím s přiznaným odkazem na tvorbu Jana Grossmana, jehož divadelní tvorba byla Pařízkovi inspirací a vzorem.

21 „Tatsächlich sagt Parizek lieber Spieler statt Schauspieler, dass diese etwas zur Schau tragen sollen, gefällt ihm offenbar nicht“ (KOBERG 2015). Ve významu, Pařízek raději říká hráč (Spieler) než hráč podívané, tedy herec (Schauspieler, od slovesa schauen, dívat se), nelíbí se mu, že by měl něco „nést k podívané“. 


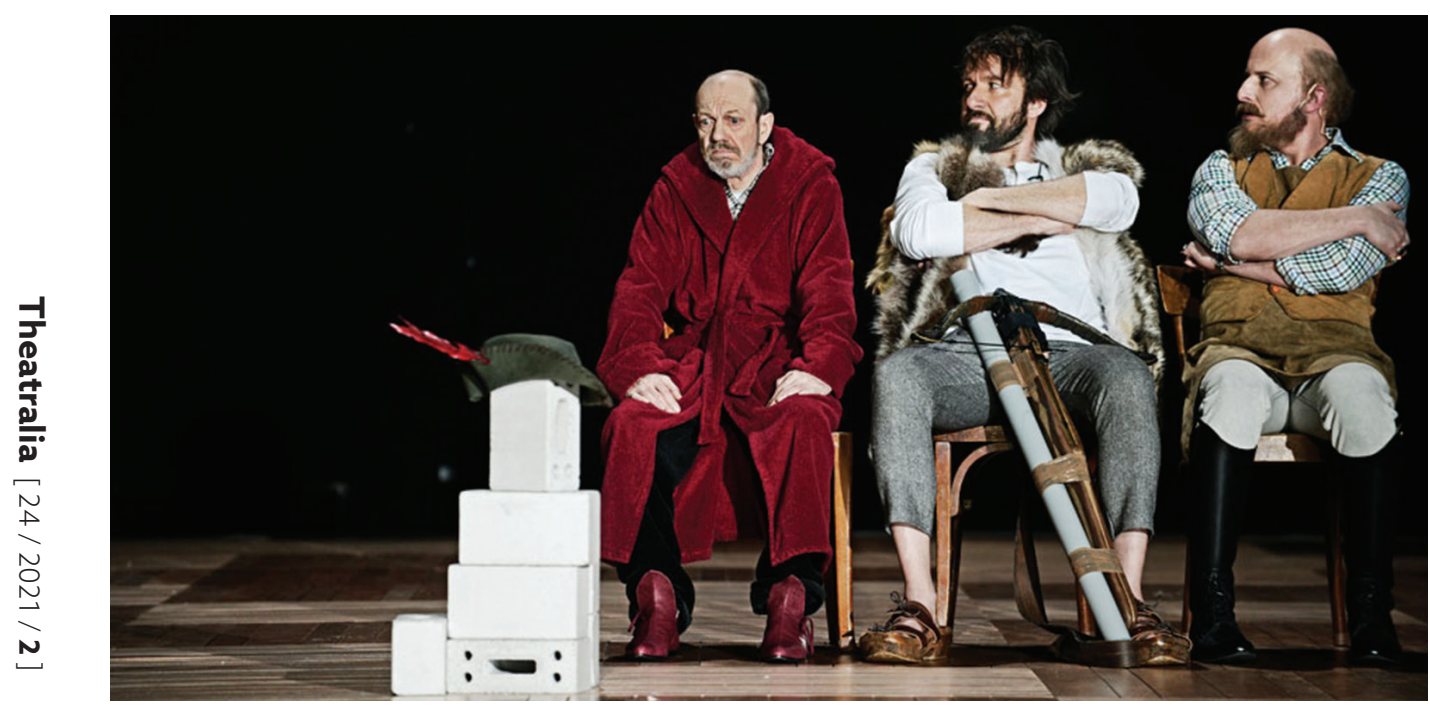

Obr. 1: Schauspielhaus Zürich, Wilhelm Tell. Zleva: Siggi Schwientek, Michael Neuenschwander a Lukas Holzhausen. (c) Toni Suter, 2013.

císaři. V Pařízkově interpretaci není Gessler černobíle zlý představitel moci. Ve scéně stavby hradby, na jevišti znázorněné několika betonovými cihlami, Frank Seppeler coby fojt Gessler žádá o pomoc švýcarský lid (Wernera - svobodného pána z Attinghausenu, Tella a Stauffachera), kteří však sedí na židlích se zkř́iženýma rukama na prsou a odmítají se s Gesslerem bavit (obr. 1).

Pařízkův Tell je vším jiným než udatným hrdinou (kterým ovšem není ani v Schillerově dramatu, v nichž přiznává svou slabost a projevuje o sobě pochybnosti). Tato Tellova individualita posiluje Pařízkův výklad Tella jako „osamoceného kovboje“22 (HALTER 2013), tak trochu nanicovatého trouby, o jehož střeleckých schopnostech lze rovněž pochybovat. Představitel Tella Michael Neuenschwander se scénou plouží ve svých dřevácích, které mu na holé šikmě spíš kloužou a činí jej nemotorným; když už nudou neví coby, opře se o svou kuši. V klíčové scéně skládání přísahy Tell vyloženě překáží, narušuje již tak groteskně inscenovaný akt zasazení meče do kamene (přesněji betonových cihel), k němuž se zástupci jednotlivých kantonů sejdou v plavkách a s ručníky, tedy jako by se chystali na př́ijemné odpoledne u jezera namísto slavnostního aktu (obr. 2). Tell kolem nich bloumá pod vlivem halucinogenních drog, vyrušuje, takže jej musejí několikrát okřiknout („Willi, bitte“ - „Willi, prosím tě“), občas je přeruší hrou na didgeridoo.

Na první pohled svévolné znevážení tohoto historicky podstatného aktu založení švýcarské federace však Pařízek posouvá do nové výkladové roviny: kromě mužů jsou zde přítomné i ženy (Stauffacherova žena Gertruda a Tellova žena Hedwiga) a není 


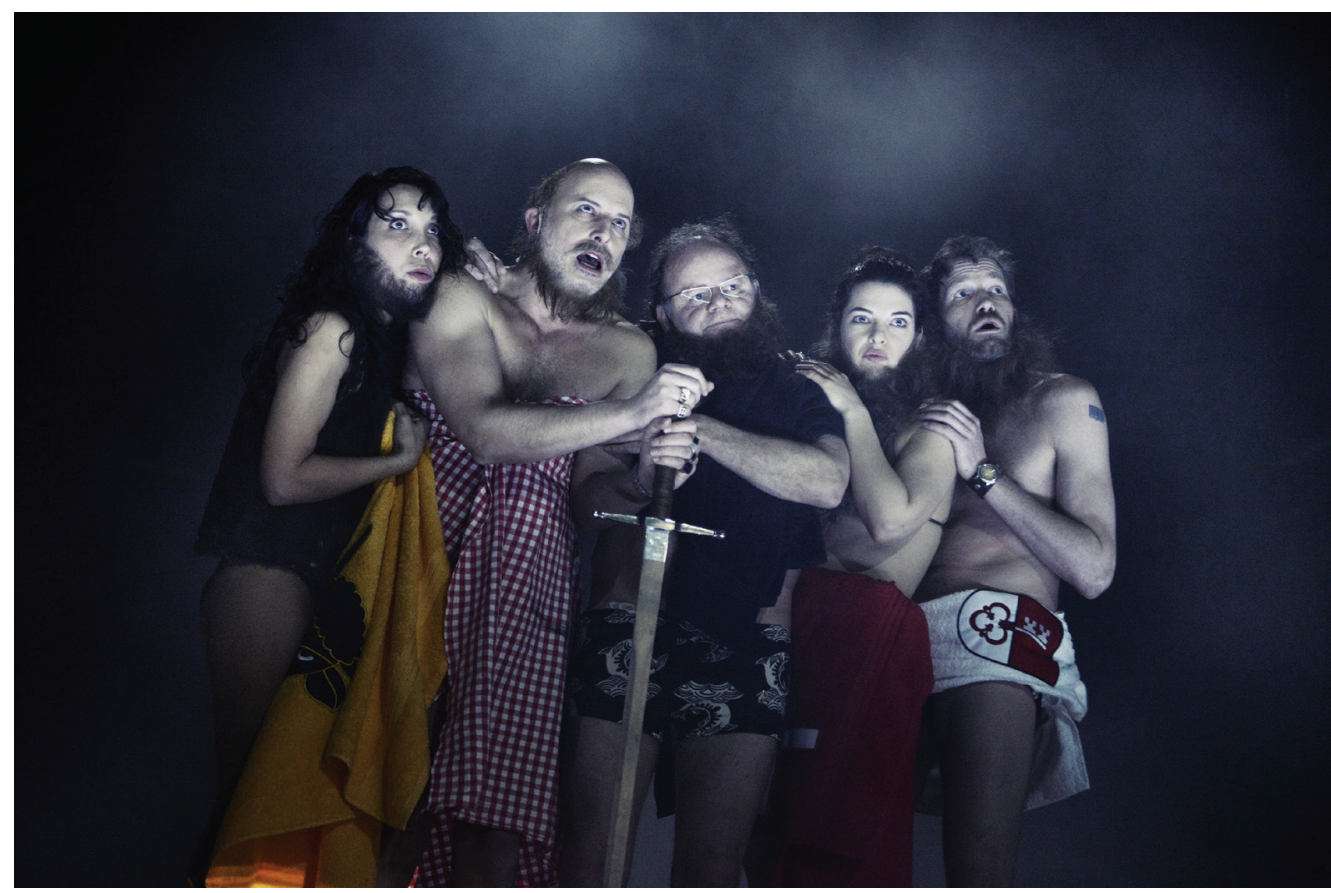

Obr. 2: Schauspielhaus Zürich, Wilhelm Tell. (c) Toni Suter, 2013.

př́iliš jisté, že by bez nich švýcarští muži zvládli př́ísahu složit. ${ }^{23}$ Pozice a úloha žen v dějinných událostech je jedno z témat Pařízkových inscenací, skrze které relativizuje výklad dějin (a nejen dějin, ale i běžných životních příběhů) čistě prostřednictvím zásluh mužů. ${ }^{24}$ Oslabení Tellovy udatnosti tak poté přímo vede k posílení úlohy jeho ženy Hedwigy (Irina Kastrinidis). Podobně rázně nakládá Gertruda (Sarah Hostettler) se Stauffacherem. Toho Lukas Holzhausen ztvárňuje skrze celou škálu mimických a verbálních hříček jako žoviálního muže z lidu, který do všeho neustále kecá (kromě švýcarské němčiny občas něco glosuje francouzsky, čímž tematizuje jazykovou heterogenitu Švýcarska), nevhodně se doptává a všechno až př́liš emočně prožívá. Tento „archetyp“ muže z lidu, až trochu burana Holzhausen, mimochodem rodilý Švýcar,

23 Během př́sahy si všichni přítomní průběžně skáčou do řeči nebo si naopak dávají přednost, nebot sami neví, co říct, což vede k celkovému grotesknímu vyznění scény. Groteskně působí např. Stauffacherovo doplnění Fürstova zvolání „Eidgenossen!“ o ženskou koncovku „-innen!“ (konvencionalizovaný německojazyčný zápis zrovnoprávňující mužský a ženský rod). Ještě podstatnější ovšem je, že Pařízek tento akt skládání přísahy proložil citáty z proslovů pravicové strany SVP (HUWILER 2018: 72), čímž poukázal na nacionalistické vyznění tohoto aktu.

24 Výrazně se tohoto tématu dotýká např. ve své inscenaci Iphigenie v Schauspielhaus Bochum (více viz MIKULOVÁ 2019). Silný akcent na ženskou sílu a její úlohu v dějinách dává Pařízek také např. ve své inscenaci Peer Gynt v Schauspielhaus Bochum (online prem. 24. 4. 2021), v níž titulní úlohu ztvárňuje žena. Režisér tímto obsazením relativizuje skutečnost, zda Peerem musel být pouze muž. Interpretační rovinu silných žen nalezneme v Pařízkově konzistentním uváděním vlastních dramatizací románů Davida Grossmana (např. Eine Frau flieht vor einer Nachricht, 24. 1. 2020 nebo zatím poslední premiéra Was Nina wusste, prem. 19. 9. 2021, obojí v Malersaal Schauspielhaus Hamburg). 


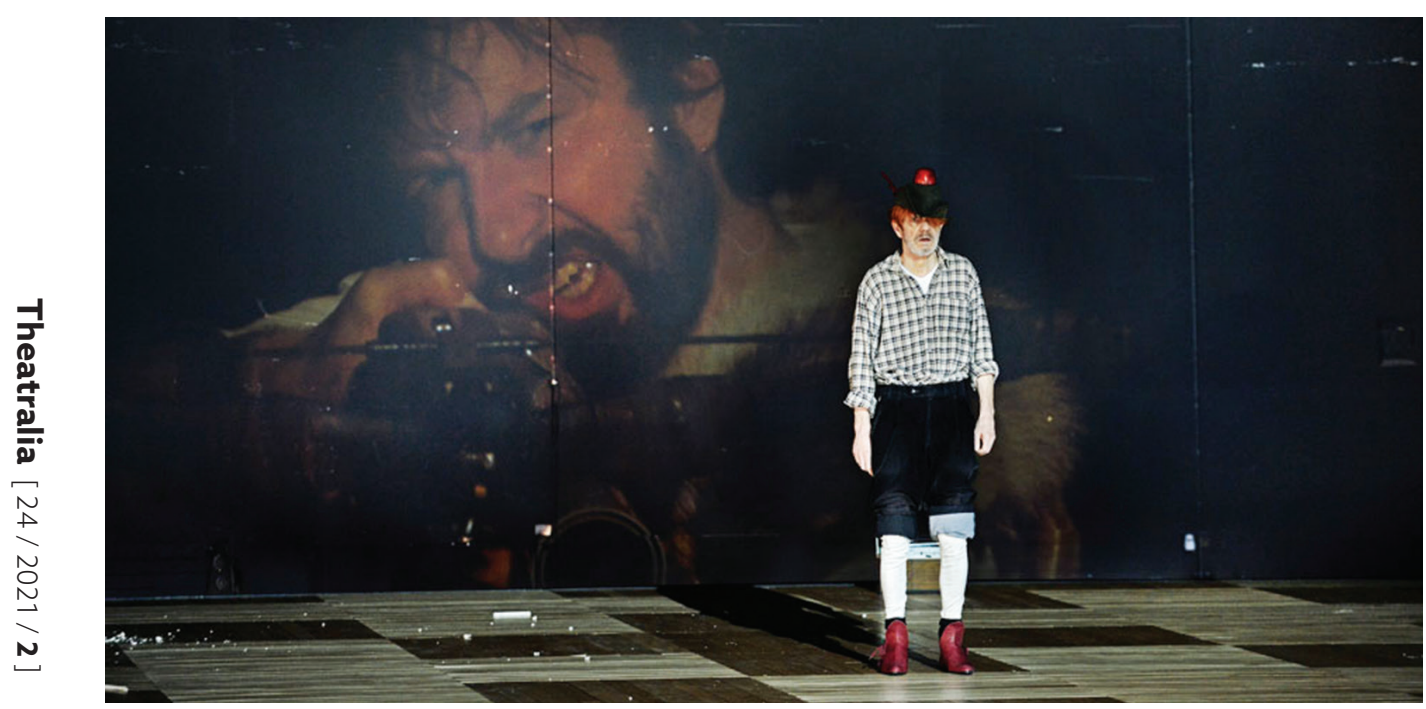

Obr. 3: Schauspielhaus Zürich, Wilhelm Tell. Michael Neuenschwander a Siggi Schwientek (zde v roli Walthera). (c) Toni Suter, 2013.

rozvine v další analyzované inscenaci Sláva a pád krále Otakara, kde ztvární příznačně švýcarského Rudolfa Habsburského. ${ }^{25}$

Inscenace se odvíjí v komickém, groteskním duchu jako sled scén z Tella, digest motivů a dramatických linií, jemuž padne za obět značná část textu. Rámec švýcarských reálií na prázdné šikmě dotváří občasný zvuk kravského zvonce, klapot dřeváků, mísení jazyků a nářečí, to vše v přiznané divadelnosti (např. sestupování ze šikmy do parteru, komunikace s technickou kabinou). Kritika o inscenaci hovoří mimo jiné jako o velkolepé satiře na švýcarskou mentalitu (např. AARGAUER ZEITUNG 2013). Satiričnost a grotesknost inscenace míří k apelativnímu závěru, jako většina Pařízkových inscenací: co se zdá být jen jako groteska k pobavení, se vyjeví jako promyšlená dekonstrukce s morálním apelem. Například klíčovou scénu střelby Tella na syna Walthera z třetího dějství totiž Pařízek přesunul až na konec své úpravy. V předposlední scéně inscenace tak Tell selže v tom, co jej učinilo slavným: svého syna po Gesslerově výzvě zastřelí (snímáno živě skrze kameru, Tell střílí z levého portálu a diváci vidí jeho výraz projektovaný na zadní horizont) (obr. 3). Zdánlivě prvoplánová provokace „českého režiséra“ vůči národnímu mýtu je však doslovena k nové interpretaci. I když je syn mrtvý, šíp se - a jak tematizují postavy v klebetivém rozhovoru, můžeme si to dosvědčit my všichni, kdo jsme tomu byli přítomni, at̉ už je to pravda, nebo ne - dotkl jablka. Aneb takto vznikají mýty: bez ohledu na nezbytnou historickou pravdivost a přesnost.

25 Přestože v této studii nepojednávám Pařízkovo první nastudování Kleistovy Die Hermannsschlacht, je příhodné pro doplnění kontextu zmínit, že v této inscenaci ztvárnil Hermanna právě Holzhausen. Při porovnání hamburského a lipského provedení, v nichž režisér vychází z podobné inscenační koncepce, je patrné posílení minimalistického jevištního provedení a také vedení herců k ještě umírněnějšímu civilnímu projevu. 
Závěrečná scéna nese dvojí symboliku: v roli malého Walthera umírá nejstarší herec curyšského souboru Siggi Schwientek, který v první části inscenace zpodobňoval postavu Barona z Attinghausenu. Ten byl zastáncem starého švýcarského uspořádání a odpůrcem příklonu země k Rakousku, k Habsburské říši. Schwientek se po smrti postavy Attinghausena převléká př́mo na šikmě do kalhot a košile a proměňuje se tak v Tellova syna. Při střelbě má na hlavě posazenou zelenou čepici, symbol Gesslerova útlaku. Švýcarský lid se však nyní, ve vidině nové svobody, obává Gesslerovy moci. ${ }^{26}$ Teprve před ní se Tell zachová „hrdinsky“ a dopustí se pomsty. Šikma (sestavená z ikonografických čtverců ve tvaru helvétských kř́rǔ̃u) před závěrečnou scénou vyjede vzhůru, až do sklonu, ve kterém je pro Tella i Gesslera obtížné se na ní udržet. Pařízek jim dopřeje ještě jedno setkání na pomyslné švýcarské skále, z níž ovšem Tell pustí Gesslera nemilosrdně dolů. Přestože sám rozhoduje o jeho osudu, ve své poslední replice Tell odkazuje k poslednímu soudu, kterého se Gesslerovi dostane po jeho smrti.

\section{"S lidmi se musí mluvit"}

V české recepci inscenace Sláva a pád krále Otakara se pozornost kritiků upírala k postavě Otakara ztvárněné českým hercem Karlem Dobrým, který v této roli hostoval na scéně rakouského Volkstheateru (obr. 4). Je to pochopitelné, protože běžně nedochází k hostování českých herců na německojazyčných profesionálních scénách. Zde však šlo v Pařízkových záměrech o více než jen exkluzivitu narativu „český herec na rakouském jevišti“. Dobrého účinkování v inscenaci, jehož opodstatnění můžeme najít v Pařízkově konceptu jazykové diverzity historicky homogenního středoevropského prostoru se společným kolektivním vědomím, však především smysluplně dotvářelo celkovou interpretaci hry, kterou Grillparzer psal na začátku 19. století tehdejším Rakouském císařství. Na tomto územním celku se vedle sebe potkávaly spisovná němčina, vídeňský dialekt, švýcarská němčina, mad’arština a další nářečí, kterými promlouvají také postavy Pařízkovy inscenace. Přemysl Otakar byl Čech, a tak ho hraje český herec, Rudolf Habsburský byl Švýcar, je tedy zpodobněn švýcarským hercem. Jenže zatímco čeština Karla Dobrého Rakušany tolik netrápila (mnohem více jeho česká výslovnost němčiny, např. AFFENZELLER 2019), tak švýcarský dialekt Lukase Holzhausena už představoval šlápnutí do vosího hnízda. Protože připomínat švýcarský původ tohoto Habsburka není na scéně Volkstheateru záhodno. Tato Grillparzerova hra totiž pro Rakušany už dvě staletí představuje především hru o významném panovníkovi, který územně a politicky posílil pozici Rakouska ve stř̌ední Evropě.

V tomto pietním duchu se také odvíjela dosavadní inscenační tradice tohoto národního mýtu, který zakonzervoval na dlouhá desetiletí v rytî́ských brněních, k nimž měli bojovníci připevněny meče připravené $\mathrm{k}$ závěrečné bitvě na Moravském poli. V Pařízkově inscenaci jako by se střetávali představitelé dvou znepřátelených gangů v mikinách

26 V opozici vǔči baronu z Attinghausenu stál jeho synovec Rudenz, který uznával habsburskou nadvládu v čele s císařem, ovšem odmítal mocenské jednání říšského fojta Gesslera. 


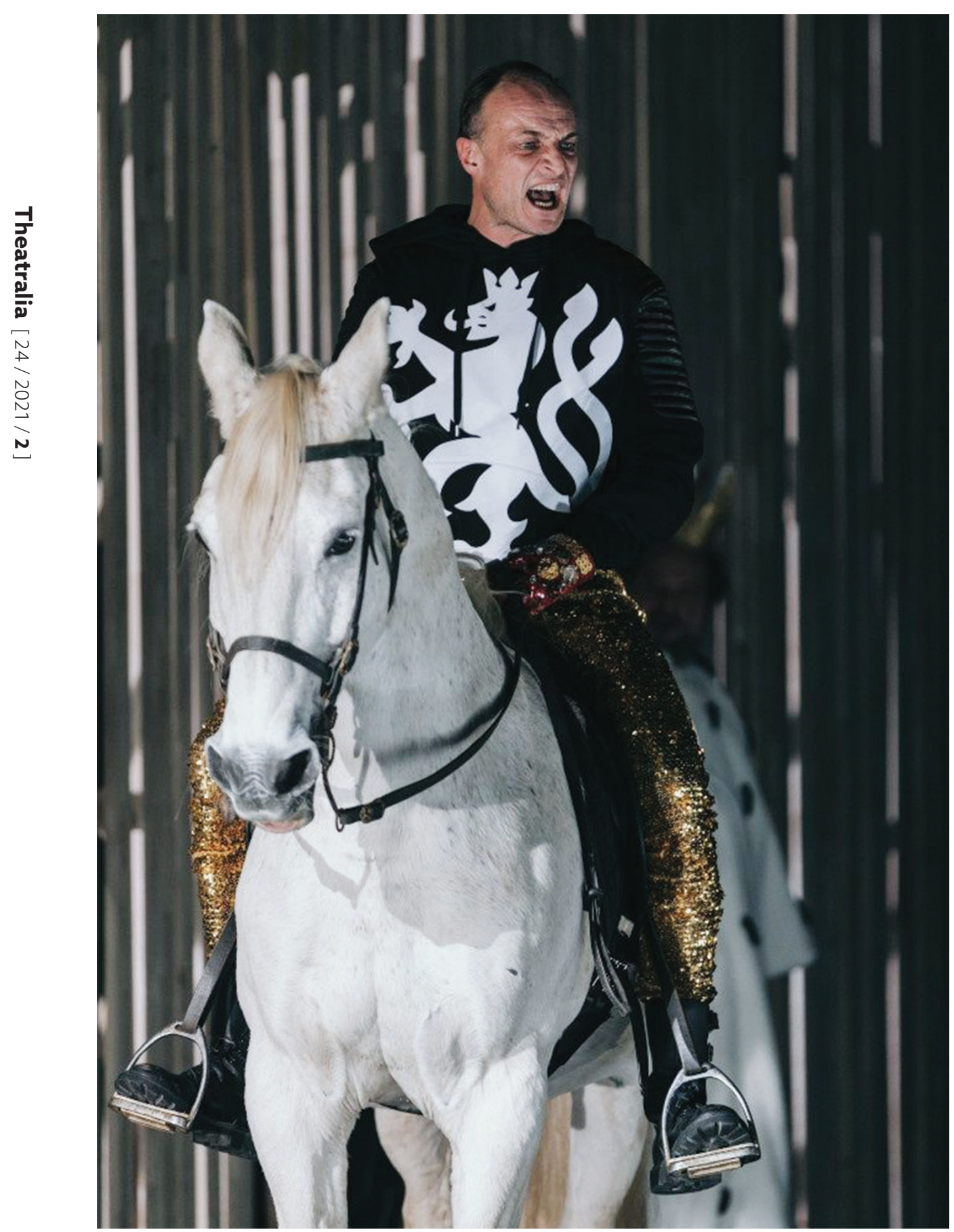

$\sqrt{3}$

Obr. 4: Volkstheater Wien. Karel Dobrý. (c) Lupis Puma, Volkstheater 2019. 
s potisky heraldických znaků (např. bílý nebo červený lev, černá orlice s červenou zbrojí). Postavy tak ostentativně ukazují svoji př́ślušnost $\mathrm{k}$ danému rodu a jejich jednání je pro diváky jasně srozumitelné právě i díky tomuto viditelnému zařazení. Koncepce Kamily Polívkové v sobě mísí stylové rozpětí, ze kterého autorka vychází při tvorbě kostýmů k Pařízkovým inscenacím: „mezi teplákovou soupravou a smokingem“27 (KOBERG 2015). Prostředí zůstává minimalisticky neutrální, od levého portálu z pohledu diváka je jeviště přetnuto diagonálou z vysokých dřevěných latí, jejichž část padá symbolicky v momentě dokonání Otakarova pádu (potupné přijetí českého a moravského léna z rukou Rudolfa Habsburkého, která jsou jen paběrky všeho, co mohl Otakar na začátku své politické cesty získat, kdyby měl dobré rádce, rozpoznal zrádce a nebyl urputně zpupný).

Otakar prohrává především svým netaktickým uvažováním. Chce získávat nová území, aniž je však pro to ochoten udělat jakékoli ústupky nebo některá čistě zištná rozhodnutí: neodhalí zradu Záviše z Falkenštejna (Peter Fasching) z českého rodu Vítkovců, který intrikuje skrze štýrského rytîre Seyfrieda Merenberga (Thomas Frank) př̀i volbě německého císaře, a neposlouchá rady a instrukce svého kancléře Brauna z Olomouce (Gábor Biedermann), které mohly zabránit ztrátě území vzniklých po rozvodu s Markétou (Rainer Galke) a vést k zisku císařské koruny. Naopak Rudolf jako by o císařskou korunu vlastně ani nikdy neusiloval, jen se mu tak přihodilo, že zůstala na jeho hlavě. To Pařízek naznačuje v groteskní scéně ze začátku inscenace, v níž vedou rozhovor Rainer Galke v crossgenderově obsazené roli Markéty a Lukas Holzhausen jako Rudolf Habsburský (zde zatím ještě jen jako Švýcar oblečený $\mathrm{v}$ bílé mikině $\mathrm{s}$ červeným lvem, znakem Habsburků, kterou po císařské volbě převleče za okrové kalhoty a sako s německou orlicí). ${ }^{28}$ Markéta si posazuje Rudolfa na svůj královský klín zahalený bílým hermelínem, který jí neustále padá a už jí zjevně překáží (nebot’ se blíží její rozchod s Otakarem), a „jen tak zkusmo“ nasazuje Rudolfovi papírovou korunku. Holzhausen předvádí etudu odmítání, načež si korunu nechá nasadit (obr. 5). Píše-li kritik Vojtěch Varyš o Tellovi, že je „nad jeho [Pařízkovy] poměry nadmíru rozverná podívaná“ (VARYŠ 2013: 56), potom v Otakarovi, této rakouské truchlohře, zachází Pařízek ještě dál, a grotesknost rozvíjí především skrze postavu Rudolfa a jeho interakci s dalšími postavami (patrná je herecká souhra Holzhausena a Galkeho). ${ }^{29}$

27 Něm.: „[...] zwischen Trainingsanzug und Smoking“ (KOBERG 2015).

28 Herce Rainera Galkeho a Lukase Holzhausena si Pařízek do svých inscenací zve opakovaně a patří k jedněm z jeho nejčastějších spolupracovníků. Společně se objevili např́íklad v jeho inscenaci Bernhardových Starých mistrů (Volkstheater, prem. 2015).

29 Je potřeba doplnit, že repríza ve Stavovském divadle ze dne 24. 11. 2019 (a její případný záznam), kterou zhlédla část divadelních kritiků, působila víc komicky než běžná vídeňská repríza. Soudím tak z porovnání tří repríz v rakouském Volkstheateru včetně premiérového uvedení. Je patrné, že herci se ve Stavovském divadle nechali mírně strhnout příznivým diváckým přijetím a opakovaným smíchem, který reagoval i na některé české aktualizace, přidané pro tuto reprízu. Smích publika složeného převážně $\mathrm{z}$ česky hovořících návštěvníků posouval také vyznění celé inscenace mnohem více směrem $\mathrm{k}$ zesměšnění rakouského panovníka, ovšem bez ostnu karikování našeho národního hrdiny. Rakouské publikum bylo v projevech smíchu v těch samých scénách (pochopitelně) zdrženlivější. 
Rudolf je v podání Holzhausena švýcarský buránek, který se svým okolím nechá oslovovat lidovým „Ruedi“30, je přece jedním z nich a „s lidmi se prostě musí mluvit“ (což Holzhausen pronáší žoviálním „otevřeným“, až nesrozumitelným švýcarským nářečím, takže ani mluvení s lidmi nevede k porozumění si s nimi). Ve své pozici si ovšem není schopný zapamatovat ani Merenburgovo jméno a historky, které vypráví, svou obhroublostí patří spíše do hospody čtvrté cenové skupiny (vynikající scéna setkání rakouského Merenberga, švýcarského Rudolfa a německého Friedricha Zollerna v podání Galkeho, který v inscenaci ztvární tři různé role). „Já jsem Švýcar, já musím být přesný“, ironizuje Pařízek Rudolfovými ústy všeobecně známou charakteristiku švýcarských hodinek, a zároveň tuto touhu po přesnosti využívá jako groteskní princip jazykových a významových hříček. Režisérova interpretace a inscenační ztvárnění neskýtá žádný prostor pro skanzen nacionalistického myšlení, repliky, z nichž by vyplývala Rudolfa majestátnost a dominantnost, Holzhausen záměrně přehrává a paroduje, aby zesměšnil trpitelství vládce rakouské země, který ani neví, kde leží Vídeň: „Tolik národů u Dunaje, v jedné monarchii - a to vše kvůli mně. Já na prvním místě a Rakousko taky, že ano?! Cítil jsem to: Pro ně bojuji, pro ně trpím - jako svatý Sebastián - Kurz (?!), krátce, jen krátce“31 (König Ottokars Glück und Ende 01:27:57).

Přestože u všech tří analyzovaných inscenací Pařízek přistupuje k úpravám textu totožným způsobem (v Otakarovi redukuje tři desítky postav pro sedm herců, přičemž někteří ztvárňují více rolí), scény ve hře o pádu krále Otakara jsou nejvíce provázané a kompaktní. Domnívám se, že se na této skutečnosti podílí především herectví Karla Dobrého, vycházející z odlišné divadelní tradice: jeho Otakar se ve svém chování proměňuje a neštěstí jeho pádu Dobrý ztvárňuje změnami hereckých poloh (zejména rezignovaností v závěrečných scénách) (obr. 6). Postavy kolem něj jsou herci vystavěny více typologicky, skrze př́ínačné charakteristické rysy, které jsou dále variovány (viz zmíněná Rudolfova lidovost). V Otakarovi Pařízek svou reduktivní úpravu, skelet, o kterém jsem hovořila výše, sémanticky zahuštuje novými interpretacemi a významy, které se realizují skrze hereckou akci. ${ }^{32} \mathrm{~V}$ závěrečné scéně inscenace se snoubí všechny výše pojmenované Pařízkovy režijní přístupy: v přiznaném divadelním zcizení a znakové zkratce Rudolf zabíjí Otakara na Moravském poli tím, že na sedícího Otakara lije divadelní krev z tuby (sám zahalen bílou řeznickou zástěrou, aby se neušpinil). Následně přehazuje vinu za zabití na svého přítele Merenberga, s nímž ještě nedávno vedl přátelské hospodské řeči,

30 Jedná se o příznačný rys Pařízkova rukopisu, že se postavy oslovují domácími tvary jmen, což ze společensky exponovaných konfliktů činí konflikty intimní (Tella oslovuji „Willi“, Rudolfa „Ruedi“, Thusnesldu v Hermannsschlacht oslovuje její muž „Thusche“).

31 České znění replik přebírám z titulků k české repríze ve Stavovském divadle. Pařízek zde skrze jazykovou hříčku připodobňuje Rudolfa k tehdejšímu, nyní už bývalému rakouskému kanceláři Sebastianu Kurzovi. Rudolfovo vybízení Merenberga a Zollerna k návštěvě Ibizy, které v inscenaci zazní, odkazuje k tzv. aféře Ibiza, kdy na základě zveřejněných odposlechů Heinze-Christiana Stracheho (FPÖ) padla v květnu 2019 koaliční vláda FPÖ s ÖVP, júž předsedá právě Sebastian Kurz.

32 Nejen skrze herectví Karla Dobrého se v tomto kontextu nabízí možné srovnání pečlivosti interpretace a jejího následného převodu na jeviště v režiích Pařízka a Petra Lébla. Zatímco Lébl jeviště zaplňoval významy i díky mnohovrstevnaté scénografii, Pařízek jeviště naopak vyprazdňuje, významy ovšem stejně jako Lébl předává skrze precizní herecké vedení. 


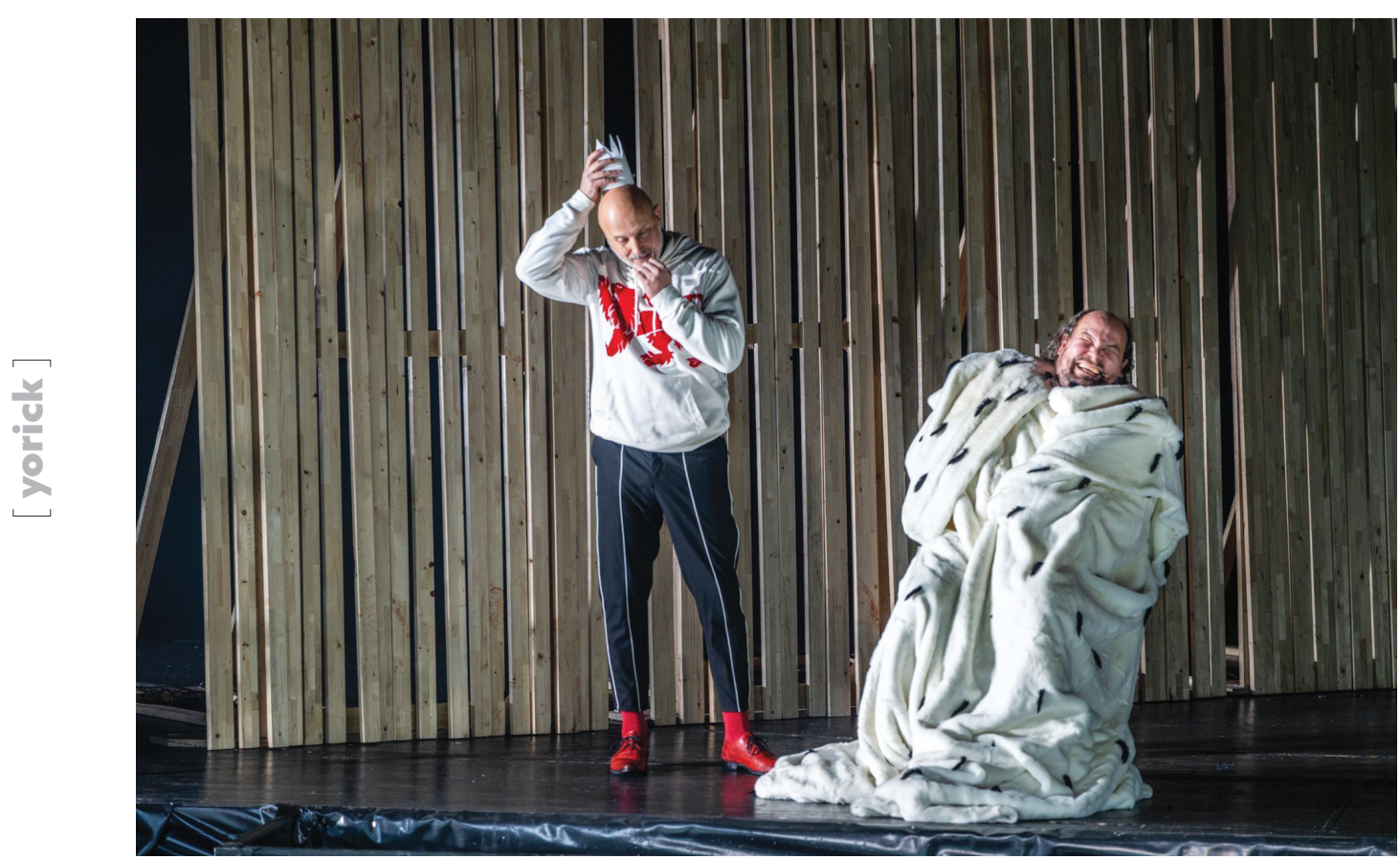

Obr. 5: Volkstheater Wien. Lukas Holzhausen a Rainer Galke. (c) KIVA, 2019 (česká repríza).

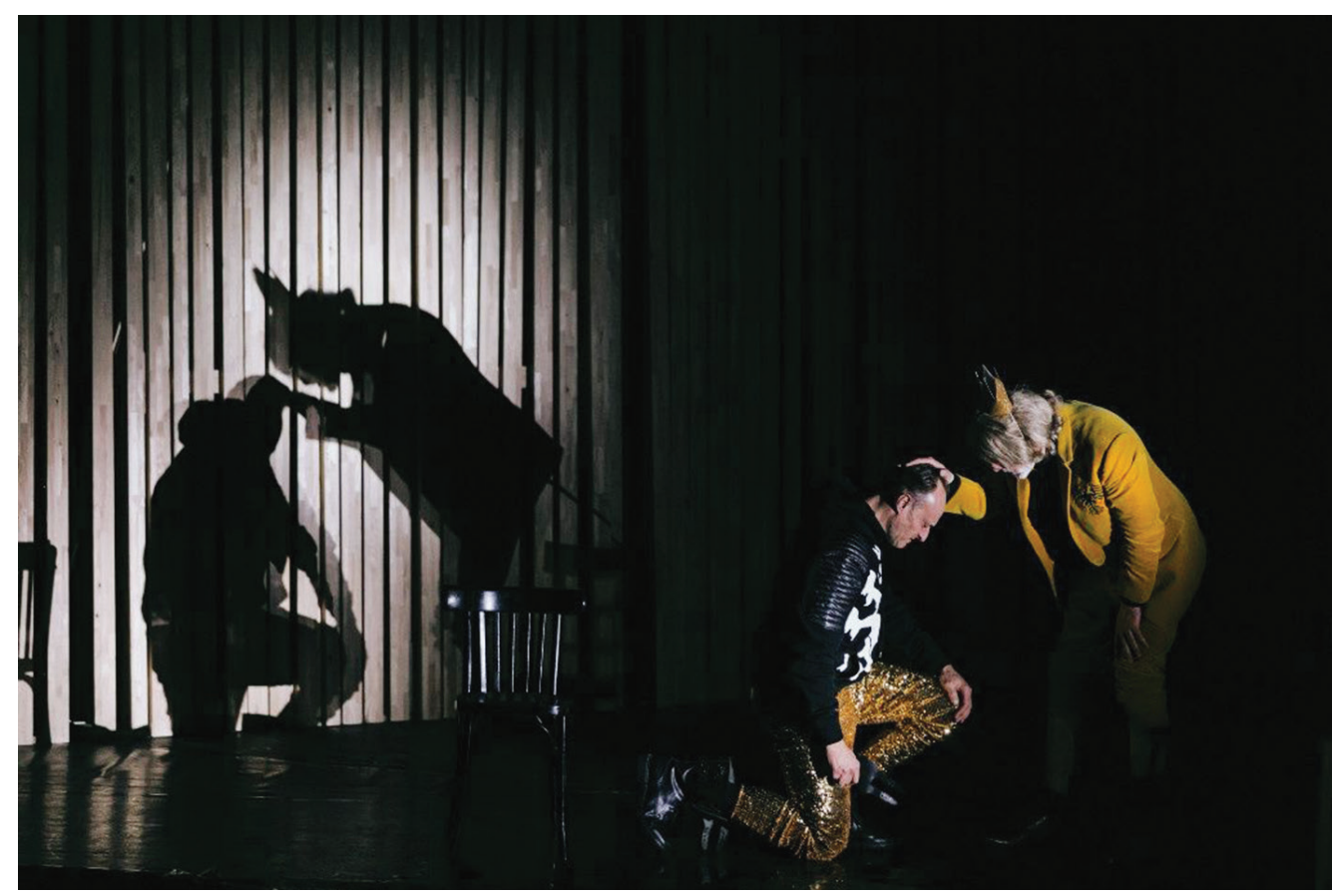

ָัָ

Obr. 6: Volkstheater Wien. Karel Dobrý a Lukas Holzhausen. (c) Lupis Puma, Volkstheater 2019. 
čemuž Otakar nepřítomně přihlíží - jinými slovy, přihlíží tomu, jak se mění historie a mýtus o hrdinném panovníkovi. Přítomní herci předstoupí frontálně před publikum, scéna setmí a v projekci vidíme v místě očí herců bílý proužek v červeném poli („vznešený bílý pruh, pruh rakouský, jak se skví vprostřed rudého pole“), tedy rakouskou státní vlajku. Když Rudolf zdraví s pohledem upřeným do publika své Rakousko „hoi“, zbylé postavy mu odpovídají „heil“ (sláva). Ovšem zvuková podobnost, v inscenaci několikrát tematizovaná, pozdravů „hoi, heil, ahoj“ zůstává jako ozvěna varováním před možným nacionalismem vládců země.

\section{„Očistit vlast od tyranů"}

Oproti individualistickému Tellovi a Rudolfovi, který má při získání císařské koruny víc štěstí než rozumu, je Pařízkův Hermann v podání Dirka Langeho od začátku inscenace nesmlouvavý intrikán a rétor mírící zcela bezohledně za svým cílem. Ten už s lidmi „jen“ nemluví, ale př́imo s nimi manipuluje. Snaží se podmanit si diváky populistickými pozdravy, potřásáním si rukou, uplatit si je jako v předvolební kampani lahvičkami s Jägermeisterem, které distribuuje do prvních řad. Celá inscenace, jejíž premiéra se uskutečnila příznačně ve státní svátek Znovusjednocení Německa (3. října), ${ }^{33}$ je Hermannovou kampaní, v níž se diváky pokouší přesvědčit, že lepší budoucnost sjednoceného národa je čeká až poté, kdy pobije římské legie s bojovníkem Varem (Markus Lerch) v čele. Jako bychom v Pařízkově inscenaci sledovali německou variaci na House of Cards [Dům z karet]. Stejně jako by se Francis Underwood nedostal na post prezidenta Spojených států amerických bez stínové, ovšem klíčové a absolutně bezmezné podpory jeho ženy Claire, Hermannův úspěch by nebyl myslitelný bez jeho ženy Thusneldy („Thusche“). Ta se propůjčí nejen ke svádění Hermannova protivníka Ventidia (Thomas Braungardt), římského legáta, kterého v závěru inscenace usmýká k smrti na své červené šále, ale kterou Hermann zapojuje také do intrik se svým rádcem Eginhardtem (jehož můžeme připodobnit k postavě Douga z Domu z karet). Ten je přítomný po celou dobu inscenace na jevišti, které stejně jako v Tellovi pokrývá holá nakloněná šikma, která se v závěru promění v bažinaté bojiště Teutoburského lesa (některé latě z dřevěných čtverců jsou vyrvány, jiné se př́ímo proboří dovnitř šikmy jako bažina). Eginhardt (Julian Kluge) v černé košili a černých kalhotách, jako stínový hráč, je přítomen většině Hermannových politických kroků, stojí vždy poslušně na opačné straně jeviště a je připraven přiběhnout na zapísknutí svého pána.

Za Hermanna kromě jeho podbízivého jednání promlouvá i jeho vzezření kultivovaného a solidního politika, dress code válečníka nahradil dress code předepsaný pro politická jednání: a Langemu při jeho konfekční vysoké postavě ${ }^{34}$ padne modrý oblek a červená kravata o něco více než Donaldu Trumpu, k němuž upomíná jako

33 Inscenace musela být po několika reprízách stažena z repertoáru ze zdravotních důvodů představitelky Thusneldy Bettiny Schmidt.

34 Dirk Lange svým vzhledem výrazně připomíná českého Pařízkova herce vyšší postavy Romana Zacha. 


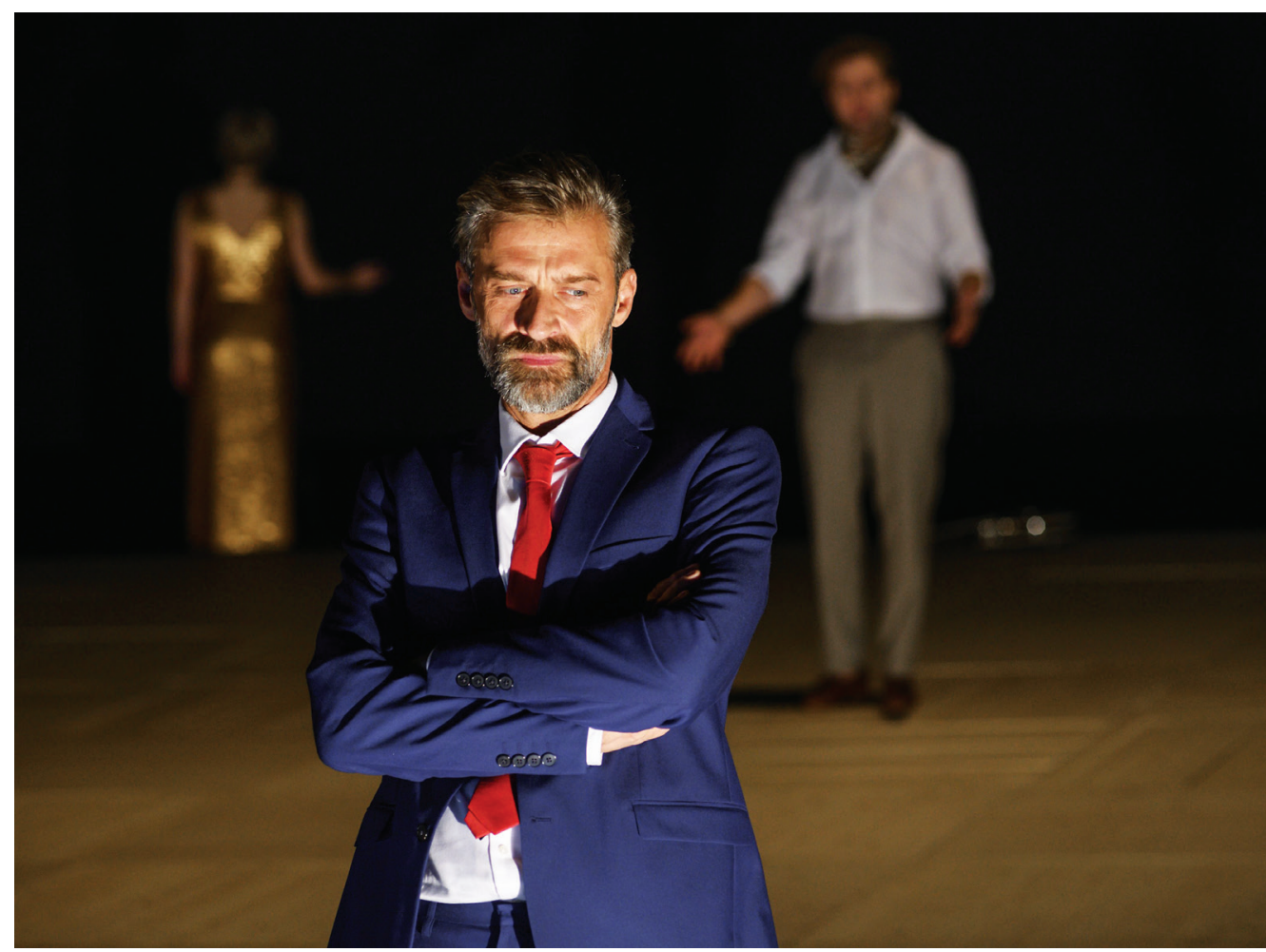

Obr. 7: Schauspiel Leipzig. Dirk Lange, Bettina Schmidt, Thomas Braungardt. (c) Rolf Arnold, 2019.

k předobrazu populistického rétora (MERBITZ 2019) (obr. 7). ${ }^{35}$ Jeho podmanivé hře s publikem, která je postavena téměř na principu divadla na divadle, je snadné podlehnout. Gesty a komunikací s publikem naznačuje, že vlastně nemohl jednat jinak, když si o to Varus sám říkal, a diváky vtahuje do své hry zbavováním se vlastní odpovědnosti: „Udělal by to každý z vás, být na mém místě“ (což je rétorika příznačná pro všechny populistické vládce). Přestože Pařízek inscenaci staví na podobných principech jako výše analyzované inscenace: redukce předlohy, perzifláž národních klišé (např. Ventidius prozpěvující si italský šlágr Felicita), jazykových nářečních hříčkách (Thusnelda učí Itala vyslovit německou dvojhlásku „eu“ ve slově Teutoburger) ${ }^{36}$ nebo zpodobnění atributů daných zemí (např. římská helma s chocholem), nevyznačuje se inscenace tak silnou groteskní hravostí a lehkostí, naopak některé scény vyznívají až přespříliš doslovně. Například když Hermann „naturalisticky“ znásilňuje Eginhardta nebo když v závěrečné

35 Dodejme, že pro inspiraci modrým oblekem a červenou kravatou nemusíme odkazovat až k zaoceánské politice: stejný politický dress code obléká např́íklad i čelný představitel krajně pravicové AfD Björn Höcke.

36 Podobně v Otakarovi učí Reiner Galke v roli Markéty vyslovit „Deutschen“ (Němci) Lukase Holzhausena coby Rudolfa Habsburského, které svým švýcarským dialektem neustále říká „Dütschen“. 


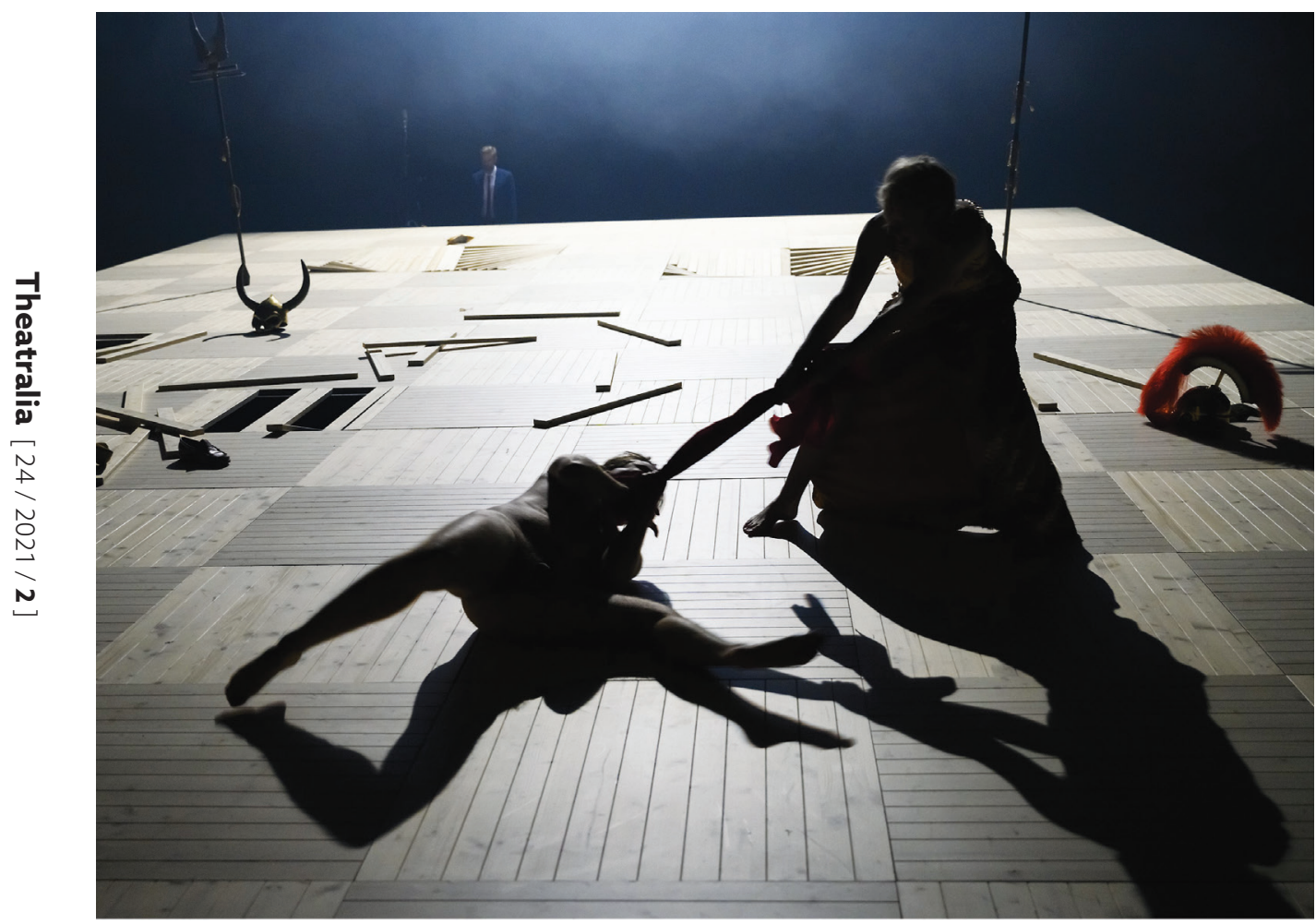

Obr. 8: Schauspiel Leipzig. Thomas Braungardt

a Bettina Schmidt, (c) Rolf Arnold, 2019.

scéně Thusnedla usmýká nahého Ventidia na své šále (obr. 8). V čistém náznakovém minimalismu vede každé vychýlení z minimalistického projevu, byt záměrné a s cílem vzbudit odpor, k pocitu bezúčelné doslovnosti.

Pařízek jako by sám cítil, že mu Kleistova předloha neumožňuje sdělit varování před nacionalismem a populismem tak implicitně jako v Tellovi a Otakarovi, a tak po děkovačce přidává jakýsi apendix, v němž postavy Hermanna a Thusneldy (lze uvažovat i o interpretaci, že v tu chvíli k nám již promlouvají herci, nikoli přímo postavy) explicitně varují před pravicovým extrémismem. ${ }^{37}$ Jejich promluva mírúcí do publika sestává z textů nebo výroků politiků a osobností spjatých s nacismem a politickou krajní pravicí (Adolfa Hitlera, zmiňovaného Björna Höckeho, Otto von Bismarcka a dalších) a také z části německé státní hymny. ${ }^{38}$ Ze vstřícného potlesku publika během premiérového večera bylo patrné, že publikum chápe, vưči čemu a proč Pařízek ve spolkové zemi

37 V zemských volbách v Sasku, které se konaly měsíc před premiérou inscenace, se na druhém místě za CDU umístila pravicová populistická strana Alternativa pro Německo (AfD) se ziskem 27,5 procenta hlasů (nárůst oproti volbám v roce 2014 činil téměř 18 procent).

38 Státní hymna se spolu s heraldickými znaky objevuje v Pařízkových inscenacích jako konotace národního uvědomění a symbol příslušnosti k danému národu. 
s výrazným zastoupením pravicovou politickou stranou varuje. Činí tak př́močařeji než v př́ípadě Tella nebo Otakara, což ovšem vyplývá i ze samotného Kleistova dramatu: V Schillerově dramatu je tím „zlým“ Gessler, v Grillparzerově je zpupným Otakar a vůči těmto Pařízek relativizuje udatnost Tella a Rudolfa. Hermann není konfrontován se zlem, protože on sám zpodobňuje nacionalistickým hledím omezené zlo - a před jemu podobným zlem Pařízek varuje právě oním závěrečným apendixem.

\section{Středoevropský „Nestbeschmutzer"}

V závěru studie se vrátím k úvodním slovům Vladimíra Mikulky, kterými tematizuje očekávání českého publika, jak to Pařízek těm Rakušanům „nandá“. Pařízek přistupuje k národním mýtům a jejich inscenační tradici s jistou drzostí (např. AARGAUER ZEITUNG 2013; PETSCH 2019). Jeho jevištní provedení Viléma Tella švýcarská kritika srovnávala s dobově podobně odvážným literárním přepracováním této legendy Maxem Frischem („Tell für die Schule“, tedy Tell pro školy, VILIGER HEILIG 2013). Odborná recepce Otakara se zmítala mezi nadšeným přijetím nového zpracování, po kritické odsudky díla, které již nemá s původním dramatem nic společného (např. nenaplněná očekávání historizující inscenace vedla divadelní vědkyni a publicistku Renate Wagner až k požadavku na odstoupení intendantky vídeňského Volkstheateru, WAGNER 2019). ${ }^{39}$ Pojetím Die Hermannsschlacht Pařízek volně navazoval na inscenační tradici nastolenou v osmdesátých letech Clausem Peymannem, jeho perspektiva však již pochopitelně vstupovala do jiného kontextu (např. do tzv. post-trumpovské doby, která je tematizována v recenzích na Die Hermannschlacht, ale také na Otakara, viz AFFENZELLER 2019). Kromě tohoto nadnárodního rámce kotveného skrze amerického zástupce populistického a mocenského vystupování (a obecně dobu mocenských populistů) se však dané inscenace vztahovaly především k lokálním kontextům daných zemí, př́ípadně spolkových republik. A tímto překračují Pařízkovy inscenace hledisko „něco někomu nandat“ směrem ke společenské a politické angažovanosti. „K textům svých inscenací přistupuji téměř jako překladatel: jde mi o to, abych tím, co jimi chtěl autor kdysi říci a čím se dotýkal svého publika, abych se tím ted' a tady dotkl publika dnešního“ (PAŘÍZEK 2005). ${ }^{40}$

V Tellovi se kriticky zrcadlila xenofobní stanoviska švýcarské konzervativní pravicové strany SVP, odmítající integraci do politického a ekonomického uspořádání Evropské unie (kterou v tomto kontextu můžeme chápat jako paralelu k integrujícímu celku Habsburské říše).$^{41} \mathrm{~V}$ červnu 2014 se dokonce uskutečnila výjimečná repríza Pařízkovy

39 Rozsah studie bohužel neumožňuje věnovat se recepci této inscenace podrobněji, nicméně šíře a rozmanitost názorového spektra, které se vyjevuje z dostupných německojazyčných a českých recenzí a ohlasů by si zasloužilo samostatnou studii.

40 Připomeňme, že v celé studii se pohybujeme ve třech časových rovinách: autoři dramat reagují na dění v jejich současnosti skrze události z minulosti (což je první paralela) a následně Pařízek skrze tato dramata pojmenovává společenské jevy své současnosti (druhá paralela). 
inscenace v reakci na únorové referendum, ve kterém Švýcaři rozhodli o zavedení imigračních limitů (HUWILER 2018: 72). V Otakarovi se přehodnocení nacionalistického hlediska jeho relativizováním a varováním před ním vztahuje k politice pravicové populistické strany ÖVP. Jak uvádí Pařízek:

Pokud se tou hrou zabýváte podrobně, lze silně cítit, jak xenofobně autor myslel, argumentoval a psal. Mluví z toho touha Rakušanů po dobrém panovníkovi nadaném od Boha a po německé ř́śíi, která německou kulturu přivede $\mathrm{k}$ rozkvětu. [...] To je v současné vládní konstelaci, kdy se ÖVP snaží FPÖ trumfovat v nacionalismu, samožrejmě veskrze lákavé téma. ${ }^{42}$ (ČTK 2019)

Lipská inscenace Die Hermannsschlacht se zase zřetelně vyjadřovala (např. prostřednictvím přidaných úryvků z projevů Björna Höckeho) k nárůstu politických preferencí pravicové strany AfD, jejímž hlavním politickým programem je odpor proti migraci do Německa. Pařízkův záměr rozrušovat interpretační a jevištní konvence nesměřuje pouze $\mathrm{k}$ divákům a kritické obci, ale také do politické roviny, čímž zřetelně vstupuje na pole politického apelativního divadla současnosti.

Při pokusu pojmenovat perspektivu, z níz Pařízek do tohoto pole vstupuje, lze připomenout zdánlivě marginální větu uvedenou v závorce v Mikulkově citaci: „(aniž by ovšem režiséra kdokoli podezíral z nějakého čechomilného vlasteneckého nadšení)" (MIKULKA 2020: 68). Nevtírá-li se do Pařízkovy interpretace „čechomilné vlastenectví“, o jaké geografické, vlastenecké nebo národnostní pozici uvažujeme? Nebo je naopak nutné $\mathrm{v}$ těchto úvahách šestistěn rozšíriit na jiný, nadnárodně pojatý geometrický útvar? Jak vyplývá z úvodu studie i následující citace, přiřazení Pařízka k té či oné vlasti se občas proměňuje podle toho, jak se to zrovna hodí. O spolupráci s curyšským divadlem říká:

V mém případě se zřejmě nepočítalo s tím, že mýtus totálně rozsekám a Tell svého synka zastřelí. Pro mne jako režiséra úspěch. Zároveň se v tom ale odráží alibistický přístup vedení: najmout si Čecha a jeho rakouského dramaturga, aby Švýcarům nasrali do jejich hnízda ${ }^{43}$ ? Takovou inscenaci měla spís udělat Barbara Frey se svým někdejším dramaturgem, autorem Lukasem Bärfussem, jinými slovy dva Švýcaři. (PAŘíZEK 2019)

Interpretaci káleče do vlastního hnízda však můžeme zkomplikovat (a posunout) slovy Heinricha Bölla: „Káleči do vlastního hnízda tak či tak vždy sedí uprostřed hnízda. [...] Je náročné, znečistit hnízdo zvenku“ (BÖLL 1973: 130). Ve volné parafrázi, je nutné dané hnízdo do nějaké míry znát, aby jej člověk mohl znečistit. Tím se vracím k úvodní koncepci Pařízka-zavlečence, člověka, který všemi uváděnými zeměmi prošel,

42 Z rakouských tvưrců, kteří se ve své tvorbě cíleně věnovali kritice politiky ÖVP a FPÖ (zejména kolem roku 2000, kdy tyto strany utvořily vládní koalici), připomeňme např́íklad Christopha Schlingensiefa nebo Elfriede Jelinek.

43 Toto vyjádření odkazuje k užívanému pojmu „Nestbeschmutzer“ (tedy káleči do vlastního hnízda), který se vztahuje k divadelní tvorbě rakouských autorů Elfriede Jelinek nebo Thomase Bernharda. 
stejně jako prošel poznáními daných kultur a mentalit, získal své vlastní zkušenostmi, které následně reflektuje ve svých režiích. Proto se domnívám, že nemá smysl uvažovat v polaritách národů a perspektiv, z nichž se Pařízek vyjadřuje, ale rozšíŕit jeho „hnízdo“ za geografické a jazykové hranice. Uvažovat o středoevropském divadelním prostoru, o původem českém divadelním režisérovi působícím v česko- a německojazyčných divadlech a vztahujícímu se ke kolektivnímu vědomí celé této kosmopolitní oblasti.

\section{Bibliografie}

\section{Primární zdroje}

Die Hermannsschlacht [divadelní záznam]. Záznam z premiéry dne 13. 10. 2019 [Recording of a Premiere]. Archiv Schauspiel Leipzig.

Die Hermannsschlacht [divadelní záznam]. Záznam zkoušky, nedatováno [Recording of a Rehearsal, without a date]. Prem. 28. 9. 2007. Archiv Schauspielhaus Hamburg.

GRILLPARZER, Franz. 2019a. König Ottokars Glück und Ende. Úprava Dušan D. Pařízek. Scénář k inscenaci [Dušan D. Pařízek's Adaptation. Production Script], 2019.

KLEIST, Friedrich von. 2019. Die Hermannsschlacht. Úprava Dušan D. Pařízek. Scénář k inscenaci [Dušan D. Pařízek's Adaptation. Production Script], 2019.

König Ottokars Glück und Ende [divadelní záznam]. Záznam z premiéry 8. 1. 2019 [Recording of a Premiere], Volkstheater Wien.

König Ottokars Glück und Ende [divadelní záznam]. Záznam z reprízy ze dne 24. 11. 2019, Stavovské divadlo v Praze [Recording of a rerun, Estates Theatre Prague].

SCHILLER, Friedrich. 2013. Wilhelm Tell. Úprava Dušan D. Pařízek. Scénář k inscenaci [Dušan D. Pařízek's Adaptation. Production Script], 2013.

Wilhelm Tell [divadelní záznam]. Záznam generální zkoušky ze dne 13. 3. 2013 [Recording of a Dress Rehearsal]. Prem. 14. 3. 2013. Archiv Schauspielhaus Zürich.

\section{Sekundární zdroje}

AARGAUER ZEITUNG. 2013. Wilhelm Tell [online]. [citováno dne 20. 2. 2021]. Dostupné online na https://www.schauspielhaus.ch/de/archiv/10936/wilhelm-tell.

AFFENZELLER, Margarete. 2019. Schräg: „König Ottokars Glück und Ende“ im Volkstheater [online]. Der Standard (9. 1. 2019). [citováno dne 15. 2. 2021]. Dostupné online na https:// www.derstandard.at/story/2000095786917/schraeg-koenig-ottokars-glueck-und-ende-im-volkstheater.

BARKHOFF, Jürgen. 2017. Wilhelm Tell als Schweizer und als Europäer - im Kontext des Schweizer Europadiskurses. In Peter-André Alt und Marcel Lepper (Hrsg.). Schillers Europa. Berlin: De Gruyter, 2017: 241-259.

BAUMAN, Zygmunt. 2006. Úvahy o postmoderni době [Contemplations of Postmodern Era]. Praha: Sociologické nakladatelství, 2006. 
BÖLL, Heinrich. 1973. Neue politische und literarische Schriften. Köln: Kiepenheuer \& Witsch, 1973.

CARLSON, Marvin. 2016. Divadlo je krajšie ako vojna [Theatre is More Beautiful than War]. Překl. Zuzana Vajdičková. Bratislava: Divadelný ústav, 2016.

ČTK. Pařízek, Dobrý i Přemysl Otakar II. Vídeňské divadlo uvede hru vycházející z české historie [online] [Pařízek, Dobrý, and Ottokar II. of Bohemia. Viennese Theatre Will Stage a Play from Czech History]. [citováno dne 30. 3. 2021]. Dostupné online na https://www.irozhlas.cz/kultura/divadlo/videnske-divadlo-parizek-dobry-premysl-otakar-ii_1901031006_pj.

DÖRNER, Andreas. 1996. Politischer Mythos und Symbolische Politik. Der Hermannmythos: zur Entstehung des Nationalbewußtseins der Deutschen. Reinbek bei Hamburg: Rowohlt, 1996.

GRILLPARZER, Franz. 2019b. Sláva a pád krále Otakara [The Fortune and Fall of King Ottokar]. Překl. Radek Malý. Praha: Městská divadla pražská, 2019.

HALTER, Martin. 2013. Rütlischwur der begossenen Pudel. Hinterwäldler mit Vorderlader und Didgeridoo: Dušan David Pařízek nimmt Schillers „Wilhelm Tell“ im Zürcher Schauspielhaus ganz ernst auf die leichte Schulter. Frankfurter Allgemeine Zeitung (19. 3. 2013).

HUWILER, Elke. 2018. Schiller's Wilhelm Tell. The National Play of Schwitzerland? In Suze van der Poll and Rob van der Zalm (eds.). Reconsidering National Plays in Europe. Cham: Palgrave Macmillan, 2018: 53-84.

KOBERG, Roland. 2015. Theater des Zivilen. Theater heute [online]. 2015. [citováno dne 15. 2. 2021]. Dostupné online na https://www.der-theaterverlag.de/theater-heute/aktuelles-heft/ artikel/theater-des-zivilen/.

MAGRIS, Claudio. 2002. Habsburský mýtus v moderni rakouské literatuře [Habsburg Myth in Modern Austrian Literature]. Překl. Jiří Pelán a Ivan Seidl. Praha: Triáda/Barrister \& Principal, 2002.

MAGRIS, Claudio. 2010. Dunaj [The Danube]. Překl. Kateřina Vinšová a Bohumil Klípa. Praha: Mladá fronta, 2010.

MACHALICKÁ, Jana. 2019. Pařízková skvělá fraška. Ve vídeňském Volkstheatru exceluje Karel Dobrý [online] [Pařízek's Brilliant Farce. Karel Dobrý Excels in Viennese Volkstheater]. Lidové noviny (26. 4. 2019). [citováno dne 15. 2. 2021]. Dostupné online na https://www. lidovky.cz/kultura/parizkova-skvela-fraska-ve-videnskem-volkstheatru-exceluje-karel-dobry. A190426_105046_ln_kultura_jto.

MERBITZ, Daniel. 2019. Hermann Trump [online]. Leipzigs Neue (prosinec 2019). [citováno dne 20. 2. 2021]. Dostupné online na http://www.leipzigs-neue.de/artikel/1912/Hermann-Trump.php.

MIKULKA, Vladimír. 2020. Obnova klidu, míru a bezpečí [Restoration of Calm, Peace, and Safety]. Svět a divadlo 31 (2020): 2: 68-75.

MIKULOVÁ, Iva. 2019. Genderově nahlíženo aneb Antické drama perspektivou D. D. Pařízka skrze Elfriede Jelinek [Viewed Through Gender or The Ancient Greek Drama from the Perspective of D. D. Pařízek Through Elfriede Jelinek]. Divadelni noviny (2019): 14: 12.

MÜNKLER, Herfied. 2017. Němci a jejich mýty [Germans and Their Myths]. Překl. Jana Zoubková. Praha: Rybka Publishers, 2017.

PAŘÍZEK, Dušan David. 2005. Něco tak pofidérního, jako je umění [online]. Rozhovor Bronislava Pražana [Something as Shady as Art. Interview by Bronislav Pražan]. Týdenik Rozhlas (7. 11. 2005). [citováno dne 20. 2. 2021]. Dostupné online na http://www.radioservis-as.cz/ archiv05/4605/46titul.htm. 
PAŘÍZEK, Dušan David a Tomáš MAŠíN. 2010. Krásný ztráty [online]. Rozhovor Michala Prokopa [Krásný ztráty. Interview by Michal Prokop]. Česká televize (2010). [citováno dne 20. 2. 2021]. Dostupné online na https://www.ceskatelevize.cz/porady/1096002521-krasny-ztraty/210562250500021/.

PAŘÍZEK, Dušan David. 2019. Osobní korespondence s Dušanem D. Pařízkem. Rozhovor Ivy Mikulové [Personal correspondence with Dušan D. Pařízek. Interview by Iva Mikulová]. (srpen a září 2019). Osobní archiv Ivy Mikulové.

PETSCH, Barbara. 2019. Grillparzer als grelle Politikfarce [online]. Die Presse (9. 1. 2019). [citováno dne 20. 2. 2021]. Dostupné online na https://www.diepresse.com/5558138/grillparzer-als-grelle-politikfarce.

POLÍVKOVÁ, Kamila. 2008. Ohne Fleiss kein Preiss. Česká sezóna [Czech Season]. Listy I (2008): 7. POLÍVKOVÁ, Kamila. 2009. Freude, Freude, Freude. Listy II (2009): 4-5.

PRAŽAN, Bronislav. 2005. Něco tak pofiderního, jako je umění [Something as Shady as Art]. Týdenik Rozhlas (7. 11. 2005): 46.

PROKOP, Daniel. 2010. Je bolavé bořit mýty [It Hurts to Destroy Myths]. Právo (14. 1. 2010).

RADIMSKÁ, Radka. 2001. Sociologie cizince: prožitek jinakosti [Sociology of Strangers: An Experience of Otherness]. Acta universitatis carolinae - philosophica et historica 1. Studia sociologica XIII (2001): 59-72.

RESLOVÁ, Marie. 2019. Když ahoj zní jako heil. Pařízkův Král Otakar dobyl Stavovské divadlo [online] [When Hello Sounds Like Heil. Pařízek's King Ottokar Captured Estates Theatre]. Aktualne.cz (27. 11. 2019). [citováno dne 20. 2. 2021]. Dostupné online na https://magazin. aktualne.cz/kultura/divadlo/stesti-a-pad-krale-otakara-parizek-recenze/r 5651ef58111311ea9b40ac1f6b220ee8/.

SIMMEL, Georg. 1997. Penize v moderni kultuře a jiné eseje [Money in Modern Culture and Other Essays]. Překl. Otakar Vochoč. Praha: SLON, 1997.

SPETH, Rudolf. 2000. Nation und Revolution. Politische Mythen im 19. Jahrhundert. Wiesbaden: Springer Fachmedien, 2000.

VARYŠ, Vojtěch. 2013. Hrdinové... [Heroes...]. Svět a divadlo (2013): 4: 56.

VARYŠ, Vojtěch. 2015. DDP v cizích službách (I) - Curych [online] [DDP in Foreign Service (I) Zürich]. Divadelní noviny (28. 4. 2015). [citováno dne 20. 2. 2021]. Dostupné online na https:/ / www.divadelni-noviny.cz/ddp-v-cizich-sluzbach-i-curych.

VILIGER HEILIG, Barbara. 2013. Wilhelm Tell für die Schule. Schillers Drama - zerlegt, gemixt und neu zusammengesetzt von tschechischen Regisseur Dušan David Pařízek am Schauspielhaus Zürich. Neue Zürcher Zeitung (16. 3. 2013).

WAGNER, Renate. 2019. Wien / Volkstheater: König Ottokars Glück und Ende [online]. Onlinemerker.com (8. 1. 2019). [citováno dne 21. 2. 2021]. Dostupné online na https://onlinemerker. com/wien-volkstheater-koenig-ottokars-glueck-und-ende/.

WESTPHAL, Sasha. 2020. Stürzt alle Denkmäler [online]. Nachkritik.de (5. 9. 2020). [citováno dne 21. 2. 2021]. Dostupné online na https://nachtkritik.de/index.php?option=com_content\&view=article\&id=18542: die-hermannsschlacht-schauspiel-koeln-oliver-frljic-verwandelt-kleists-wildes-historiendrama-in-ein-kuehles-lehrstueck-ueber-politik-und-geschichte\&catid=84\&Itemid= 100190 . 


\section{Mgr. Iva Mikulová, Ph.D.}

Masarykova univerzita, Filozofická fakulta

Katedra divadelních studií

Arna Nováka 1, 60200 Brno, Česká republika

ivi.mikuli@mail.muni.cz

Iva Mikulová vystudovala magisterský obor Učitelství pro 2. stupeň ZŠ (ČJ-NJ) na Pedagogické fakultě Univerzity Palackého v Olomouci a bakalářský obor Teorie a dějiny divadla na Filozofické fakultě Masarykovy univerzity. V roce 2016 dokončila doktorské studium na Katedře divadelních studií FF MU obhajobou práce na téma Divadelní režisér Karel Novák (1916-1968). $\checkmark$ letech 2012-2014 pracovala v Městském divadle ve Zlíně (MDZ) jako archivářka a lektorka dramaturgie. Spolu s Marcelem Sladkowským je autorkou knihy Městské divadlo Zlín. 70. sezon (2015). V současné době pracuje jako odborná asistentka na Katedře divadelních studií FF MU a je členkou Týmu pro výzkum moderního českého divadla Oddělení 20. století a literatury současné Ústavu pro českou literaturu AV ČR, v. v. i. Věnuje se českému divadlu 20. století a divadelní kritice.

Iva Mikulová holds an MA degree in Teaching Czech and German Languages in Secondary Schools from Palacký University, Olomouc, and a BA degree in Theatre History and Theory from Masaryk University, Brno. She received her PhD in 2016 at the Department of Theatre Studies, Masaryk University, having defended her doctoral thesis 'Theatre Director Karel Novák (1916-1968)'. She worked as an archive manager and dramaturg's assistant at the Zlín City Theatre (MDZ) in 2012-2014. With Marcel Sladkowski, she co-authored a monograph Městské divadlo Zlín, 70 sezon (2015). Currently, she is an assistant professor at the Department of Theatre Studies, Masaryk University, Brno, and she also has a research position at the Department of the $20^{\text {th }}$ Century and Contemporary Literature, Institute of Czech Literature of the CAS. Her major field of interest is Czech theatre in the $20^{\text {th }}$ century and theatre criticism. 
